\title{
Synopsis of the tribe Cocoseae Mart. (Arecoideae, Arecaceae) in the state of Maranhão, Brazil
}

\author{
Gustavo Pereira Lima ${ }^{1 *}$ \& Eduardo Bezerra de Almeida Jr. ${ }^{2}$ \\ ${ }^{1}$ Universidade Federal do Maranhão, Programa de Pós-Graduação em Biodiversidade e Conservação, Cidade \\ Universitária Dom Delgado, São Luís, MA, Brasil \\ ${ }^{2}$ Universidade Federal do Maranhão, Departamento de Biologia, Cidade Universitária Dom Delgado, São \\ Luís, MA, Brasil \\ *Corresponding author: Gustavo Pereira Lima, e-mail: gustavo-plima@hotmail.com
}

LIMA, G.P., ALMEIDA JR., E.B. Synopsis of the tribe Cocoseae Mart. (Arecoideae, Arecaceae) in the state of Maranhão, Brazil. Biota Neotropica 20(2): e20190922. https://doi.org/10.1590/1676-0611-BN-2019-0922.

\begin{abstract}
This study presents a synopsis of the tribe Cocoseae (Arecaceae) for the Maranhão state, which was based on the descriptive analysis of voucher specimens of national and international herbaria, from loans, collection visits, digital platforms, and materials collected in expeditions. Twenty-five species belonging to seven genera were identified. The genus Bactris Jacq. ex Scop. was the most representative with seven species, followed by Attalea Kunth. (five spp.), Syagrus Mart. (five spp.), Astrocaryum G. Mey. (three spp.), Desmoncus Mart. (three spp.), Acrocomia Mart (one spp.), and Allagoptera Nees (one sp.). Four new records of occurrence were found for Maranhão: Allagoptera leucocalyx (Drude) Kuntze, Attalea barreirensis Glassman, Attalea phalerata Mart. ex Spreng. and Syagrus glazioviana (Dammer) Becc. This paper presents a taxonomic key for the species, as well as geographic distribution maps and photographic plates with the distinguishing characteristics for each taxon. Besides the taxonomic characteristics, common names, ecological data, and conservation status are included.
\end{abstract}

Keywords: palms, Arecoideae, geographic distribution, taxonomy.

\section{Sinopse da tribo Cocoseae Mart. (Arecoideae, Arecaceae) no estado do Maranhão, Brasil}

Resumo: Este trabalho apresenta uma sinopse da tribo Cocoseae (Arecaceae) para o estado do Maranhão, embasada na análise descritiva de amostras de herbários nacionais e internacionais, provenientes de empréstimos, visitas aos acervos e consultas em plataformas digitais, além de materiais coletados em expedições. Foram identificadas 25 espécies, pertencentes a sete gêneros. Bactris Jacq. ex Scop. foi o gênero mais representativos com sete espécies, seguido de Attalea Kunth. (cinco spp.), Syagrus Mart. (cinco spp.), Astrocaryum G. Mey. (três spp.), Desmoncus Mart. (três spp.), Acrocomia Mart. (uma spp.) e Allagoptera Nees (uma spp.). Foram encontrados quatro novos registros de ocorrência para o território maranhense: Allagoptera leucocalyx (Drude) Kuntze, Attalea barreirensis Glassman, Attalea phalerata Mart. ex Spreng. e Syagrus glazioviana (Dammer) Becc. É apresentada neste artigo uma chave taxonômica para as espécies, além de mapas de distribuição geográfica e pranchas fotográficas com características distintivas para cada táxon. São incluídos, além das características taxonômicas das espécies, nomes populares, informações ecológicas e status de conservação..

Palavras-chave: palmeiras, Arecoideae, distribuição geográfica, taxonomia. 


\section{Introduction}

Arecaceae Bercht. \& J. Presl is one of the largest and most important phanerogamic families in tropical regions, both in number and abundance. Moreover, it has ecological and economic importance, being reported as the third most relevant family for humans (Johnson 1998, Zambrana et al. 2007, Balslev et al. 2016). According to the current classifications, the family belongs to Arecales along with Dasypogonaceae and it is classified into five subfamilies: Arecoideae, Calamoideae, Coryphoideae, Ceroxyloideae, and Nypoideae (APG IV 2016, Baker \& Dransfield 2016). In Brazil, 37 genera and 296 species (Flora do Brasil 2020 under construction) are recognised, which makes the country one of the largest centers of diversity for this family in South America (Pintaud et al. 2008).

Cocoseae belonging to Arecoideae subfamily stands out among the tribes of Arecaceae in Brazil. It is abundant in many plant formations and has several species of sociocultural and economic value for local Brazilian communities (Pintaud et al. 2008, Noblick et al. 2013, Meerow et al. 2015). This tribe consists of 17 genera, which were grouped in this clade because they showed inflorescence associated with a single prophyll, woody peduncular bract, usually triovulated gynoecium, and thick and hard endocarp, with three clearly defined pores (Noblick et al. 2013, Meerow et al. 2015, Noblick \& Meerow 2015, Baker \& Dransfield 2016).

In the Brazilian state of Maranhão, that is situated in a transition area between Amazon, Cerrado and Caatinga biomes, there is the occurrence of 26 species belonging to the tribe Cocoseae (Flora do Brasil 2020 under construction). Nonetheless, this information about the species richness in Maranhao is different from what was pointed out by Lorenzi et al. (2010) and Pinheiro (2011). These divergences reinforce the existence of gaps in taxonomic knowledge in this transition region, despite the researches carried out lately.

Considering the relevance of this tribe and the need for further taxonomic studies to solve the disagreements regarding the tribe in Maranhão, the present study aims to elaborate the synopsis of the native species of Cocoseae in the State in order to contribute with the identifications and to increase the knowledge about the species in this region. In this sense, this study presents an identification key for genera and species, as well as taxonomic notes, distribution maps, photographic plates, ecological information, commom names, and conservation status for all taxons.

\section{Material and Methods}

\section{Study area}

The Brazilian state of Maranhão is located in the Northeast region of Brazil with a territorial extension of approximately $331,983 \mathrm{~km}^{2}$. It is situated in a transition area, between three Brazilian macroregions (North, Northeast, and Central-West), and consequently, the State has typical climatic-ecological characteristics (IMESC 2008). The vegetation consists of fragments of Amazonian forest in the western portion, mangroves and restingas in the coast, and Cerrado in the southern and eastern regions. Moreover, it should also be highlighted the ecotonal zones located in the central region, in which there is an overlap of Amazon and Cerrado elements (Muniz 2006).

\section{Taxonomic treatment}

The taxonomic treatment of the Cocoseae tribe was based on samples from the following national herbaria: BHCB, CEN, HEPH,
IPA, MAR, MBM, MG, MOSS, SLUI, SP, TEPB, and UB. In addition to these samples, images of collections from international $(\mathrm{F}, \mathrm{MO}$, $\mathrm{NY}$, and US) and national (ALCB, IAN, and RB) herbaria, available on the digital platforms Specielink (http://splink.cria.org.br/), Reflora (http://reflora.jbrj.gov.br/) and New York Botanical Garden (http:// sweetgum.nybg.org/) were analyzed. All herbaria acronyms previously mentioned follow Thiers (continuously updated). At the same time, sporadic field expeditions were carried out in 2016 and 2017 in the towns of Cândido Mendes (01'51'23.6"S, 45\%48'16.7'W) and Colinas ( $\left.06^{\circ} 00^{\prime} 04.9^{\prime} \mathrm{S}, 44^{\circ} 22^{\prime} 52.6^{\prime} \mathrm{W}\right)$, in order to collect complementary materials. These collected plants were herborized according to the usual botanical methodology (Dransfield 1986, Martins \& Filgueiras 2010) and deposited in the Maranhão herbarium (MAR).

The identifications of the genera and species were made based on specialized literatures (Henderson 1990, Kahn 1990, Henderson et al. 1995, Moraes 1996, Glassman 1999, Henderson 2000, Lorenzi et al. 2010, Henderson 2011, Martins et al. 2015, Noblick 2017, Noblick 2019, Flora do Brasil 2020 under construction), as well as comparisons with images of type collections available on the digital platforms mentioned above. The protologues and the spelling of the scientific names were verified in the original publications and the databases, Flora do Brasil 2020 (under construction), Palmweb (2019), and Tropicos (2019). Morphological descriptions followed the terminologies proposed by Harris \& Harris (1994) and Palmweb (2019). When possible, the steps of identification key were elaborated with vegetative characters of easy comprehension.

Information concerning geographic distribution, habitat, common names, and flowering and fruiting records were obtained from the examined exsiccates and the literature. Photographic plates were assembled and edited using GIMP 2.10.6 (GIMP Team 2019), in order to highlight the distinctive characters between the species. Moreover, maps were made with QGIS 3.4 software (QGIS Development Team 2019) to show the distribution of the species in Maranhão.

The status of conservation was evaluated considering IUCN (2012) criteria B1 (Extent of Occurrence-EOO). The EOO was estimated from a Minimum Convex Polygon (MCP) plotted to include all known points of a species. This analysis was carried out with QGIS 3.4 software. For the data matrix required for the calculation of criteria B1, the original geographical coordinates of all examined samples were used. In addition, when it was possible, the approximate coordinates of the non-georeferenced specimens were also used. The taxa that had less than three distinct geographic coordinate records were classified as Data Deficient (DD), due to the impossibility of delineating the MCP from a small information set.

\section{Results and Discussion}

In the state of Maranhao, a total of 25 native species distributed in seven genera were identified. Bactris is the largest genus with seven species, followed by Attalea (five spp.), Syagrus (five spp.), Astrocaryum (three spp.), Desmoncus (three spp.), Acrocomia (one spp.), and Allagoptera (one spp.). In addition to these native species, other species such as Attalea dahlgreniana (Bondar) Wess.Boer, Attalea $\mathrm{x}$ teixeirana (Bondar) Zona and Cocos nucifera $\mathrm{L}$. are mentioned to occur in Maranhao (Balick et al. 1987, Henderson et al. 1995; Pinheiro 
2011; Flora do Brasil 2020 under construction). A. x teixeirana is a fertile hybrid between Attalea eichleri (Drude) A.J.Hend. and Attalea speciosa Mart. ex Spreng., A. dahlgreniana is a possible hybrid between Attalea maripa (Aubl.) Mart. and Attalea speciosa, whereas C. nucifera is a palm tree widely cultivated in the Brazilian coast and possibly naturalized. However, it is important to say that these species were not treated taxonomically in the present synopsis.

According to Lorenzi et al. (2010) and Flora do Brasil 2020 (under construction), Allagoptera campestris (Mart.) Kunt, Astrocaryum jauari Mart. and Bactris major Jacq. var. major are palm trees that occur in Maranhão. However, no voucher plant materials were deposited in herbaria for these species and they were not observed in our expeditions. Thus, the three taxa were not listed among the Cocoseae species in this study. On the other hand, four new occurrence records for Maranhao were found: Allagoptera leucocalyx (Drude) Kuntze, Attalea barreirensis Glassman, Attalea phalerata Mart. ex Spreng., and Syagrus glazioviana (Dammer) Becc. The species Allagoptera leucocalyx and Attalea phalerata had been previously cited by Pinheiro (2011) for Maranhão. Nevertheless, they were still considered of uncertain occurrence, due to the lack of information regarding the voucher plant material and, consequenty, of a more precise location of their populations.

Cocoseae Mart., Anal. Fam. P1. 56. 1829.

Type: $\operatorname{Cocos} \mathrm{L}$.
Solitary or clustered, armed or unarmed, pleonanthic, monoecious palm. Stem underground and short, or aerial and erect, sometimes prostrate or climbing, smooth, striated, or covered with remnants leaf sheaths. Entire, bifid or pinnate leaves, marcescent or abscising neatly; sheath open or closed, usually disintegrating into a mass of fibres; petiole short or long; ocrea absent or present; rachis absent, short or long, straight or arched; pinna linear, lanceolate, sigmoid or of other forms, regularly or irregularly arranged on the rachis; cirrus absent or present. Inflorescence intrafoliar or interfoliar, unbranched or branched up to second order; single prophyll, tubular, 2-keeled; peduncular bract longer than the prophyll, almost always single, tubular, usually persistent and woody, with varied shapes and sizes. Flowers unisexual, actinomorphic or asymmetric, sessile or pedicellate, solitary or arranged in dyads, triads, or tetrads. Staminate flower; sepals $3(-4)$, free or connate, imbricate or valvate; petals (1-) 3 (-8), free or connate, imbricate or valvate; stamens (3-) $6(-120)$, filaments free or adnate to the base of the petals, anthers straight or twisted and coiled, basifixed to dorsifixed, introrse or latrorse; pistillode absent or present. Pistillate flower; sepals 3 , free or connate, commonly imbricate; petals 3, free or connate, imbricate or valvate; staminodes absent or present, free or forming a staminodial ring. Gynoecium syncarpous, usually trilocular, always 1 ovule per locule. Fruit with color, size, and variable shape; smooth or scaly epicarp, splitting or not at maturity; fleshy or dry mesocarp, fibrous or starchy; thick and stony endocarp, with 3 or more germination pores; seed 1-many, with endosperm homogeneous or ruminate.

\section{Identification key to native species of the tribe Cocoseae from Maranhão state, Brazil}

1. Palm unarmed.

2. Inflorescence unbranched with densely clustered flowers around the rachis

2. Allagoptera leucocalyx

2'. Inflorescence unbranched or branched, but without densely clustered flowers.

3. Inflorescence of one type on the same plant, with both staminate and pistillate flowers (androgynous)

Syagrus

4. Palm acaulescent with short underground stem; pinnae 15-31 along each side of the rachis; middle pinnae $0.4-0.8 \mathrm{~cm}$ wide

23. Syagrus glazioviana

4'. Palm caulescent with above-ground developed stem; pinnae $>40$ along each side of the rachis; middle pinnae more than $1 \mathrm{~cm}$ wide. 5. Stem covered with remnants leaf sheaths.

22. Syagrus comosa

5'. Stem smooth or striated, not covered with remnants leaf sheaths.

6. Apex of the rachilla devoid of any flowers, coiled like noodles

25. Syagrus vermicularis

6'. Apex of the rachilla without these characteristics.

7. Pinna with raised cross-veins, mainly visible on the adaxial surface

24. Syagrus inajai

7'. Pinna without raised cross-veins.

21. Syagrus cocoides

3'. Inflorescence of two or three types on the same plant, simultaneously with staminate, androgynous, and very rarely pistillate inflorescences

8. Palm acaulescent with underground stem.

9. Rachillae of the staminate and androgynous inflorescences spirally arranged around the rachis; stamen with straight anther; fruit with only one seed.

6. Attalea barreirensis

9'. Rachillae of the staminate and androgynous inflorescences arranged on only one side of the rachis; stamen with spirally twisted and coiled anther; fruit with three or more seeds.

7. Attalea eichleri

8'. Palm caulescent with above-ground developed stem.

10. Leaves spirally arranged around the stem, visibly organized in five or six rows; stamens longer than the petals (exserted stamens)

10'. Leaves spirally arranged around the stem, but not organized in rows; stamens shorter than the petals.

8. Attalea maripa 
11. Stem covered with remnants leaf sheaths; middle pinnae distributed irregularly in groups and arranged in different planes along the rachis; stamen with straight anther; fruit $4.5-7 \mathrm{~cm}$ long.

11'. Stem not covered with remnants leaf sheaths; middle pinnae distributed regularly and arranged in the same plane along the rachis; stamen with spirally twisted and coiled anther; fruit 7.5-12 cm long

10. Attalea speciosa

1'. Palm armed.

12. Palm climbing; apex of the leaf modified into cirrus (an extension of the rachis, armed with acanthophylls)

Desmoncus

13. Rachis spines and petiole greater than $1 \mathrm{~cm}$ long, straight with slightly swollen bases

18. Desmoncus horridus subsp. horridus

13'. Rachis spines and petiole less than $1 \mathrm{~cm}$ long, recurved with markedly swollen bases.

14. Spines in the entire cirrus

19. Desmoncus parvulus

14 '. Spines only on the proximal and abaxial part of the cirrus 20. Desmoncus polyacanthos

12'. Non-climbing palm; apex of the leaf not modified.

15. Pistillate flowers and fruits arranged in the rachilla; pinnae usually concolorous....

Bactris

16. Inflorescence branched up to 1 order and with numerous rachillae, usually more than 10 .

17. Rachilla filiform, $<1 \mathrm{~mm}$ in diameter; fruit armed.

11. Bactris acanthocarpa var. exscapa

17'. Rachilla not filiform, $>1 \mathrm{~mm}$ in diameter; fruit unarmed.

18. Sheath, petiole, and rachis with yellowish spines; fruit 1-1.6 cm in diameter, black-purplish when mature

12. Bactris brongniartii

$18^{\prime}$. Sheath, petiole, and rachis with grayish or brownish spines; fruit $0.5-0.8 \mathrm{~cm}$ in diameter, orange-red when mature

13. Bactris campestris

16'. Inflorescence unbranched or branched up to 1 order and with few rachillae, usually less than 5 .

19. Fruit globose, $<1 \mathrm{~cm}$ in diameter.

20. Palm usually with small spines $(\leq 3 \mathrm{~mm})$ on the apex margins of the leaf blades, and rarely on sheaths and petiole; fruit unarmed

16. Bactris simplicifrons

20 '. Palm with spines on the sheath and petiole, up to $4.5 \mathrm{~cm}$ long; fruit armed.

14. Bactris hirta var. pectinata

19'. Fruit obovoid or ellipsoid, $>1 \mathrm{~cm}$ in diameter.

21. Pinna sigmoid or elliptic-lanceolate, with filiform apex; inflorescence unbranched; fruit obovoid, $1.9-2.2 \mathrm{~cm}$ long

17. Bactris tomentosa

21'. Pinna linear-lanceolate; inflorescence branched up to first order with 2-3 rachillae; fruit obovoid or ellipsoid, 2.6-4 cm long .......

15. Bactris major var. infesta

15'. Pistillate flowers and fruits arranged on the proximal parts of the rachilla only; pinnae markedly discolorous.

22. Pistillate flower with sepals and petals distinct; fruit globose, $>3.5 \mathrm{~cm}$ in diameter

1. Acrocomia aculeate

22 '. Pistillate flower with sepals and petals comparable in shape and size; fruit subglobose, obovoid or ellipsoid, $<3 \mathrm{~cm}$ in diameter

Astrocaryum

23. Palm acaulescent; inflorescence is borne near ground level

3. Astrocaryum campestre

23'. Palm caulescent; inflorescence is not borne near ground level.

24. Rachilla less than $10 \mathrm{~cm}$ long; pistillate flower armed with small black spines; fruit splitting at maturity

24'. Rachilla greater than $10 \mathrm{~cm}$ long; pistillate flower unarmed; fruit not splitting at maturity

4. Astrocaryum gynacanthum

5. Astrocaryum vulgare 
1. Acrocomia aculeata (Jacq.) Lodd. ex Mart., Hist. Nat. Palm. 3(8): 286. 1845. Figure 1a-d.

Solitary and caulescent palm with up to $15 \mathrm{~m}$ tall that can be characterized by its columnar stem usually covered with remnants leaf sheaths, globose crown of leaves on the tip of the stem, peduncular bract externally covered with velutinous brownish indument, pistillate flowers with sepals and distinct petals, and globose fruits, $3.5-4.5 \mathrm{~cm}$ in diameter, with yellowish-green epicarp and yellow-orange mesocarp.

Common names: macaúba, parena (Guajajara), bocaiúva, mucajuba, and mucujá.

Distribution and ecology: A species of broad distribution in America, occurring from Mexico to Argentina. It is found in open savannas, seasonal forests, or frequently in disturbed areas (Henderson et al. 1995, Lorenzi et al. 2010, Pinheiro 2011). The distribution of Acrocomia aculeata was highly influenced by human action, given that it was introduced in some areas in Mexico and Central America (Lentz 1990). In Maranhão, samples were collected in the north and central regions of the State (Figure 2a), with flowers in April and fruits from March to September. Scariot et al. (1991) indicate the flowering period of $A$. aculeata between August and December and fruiting between June and March in the Brazilian Central Plateau.

Conservation: According to IUCN (2012) criteria, this species is classified as Least Concern (LC) for Maranhão, due to its large extent of occurrence $\left(59,564.003 \mathrm{~km}^{2}\right)$.

Material examined: BRAZIL, MARANHÃO: Amarante do Maranhão, 05³4'48”S, 46²6'24”W, 05.VII.2017, fr., R.M.G. Konopczyk 215 (UB); Bom Jardim, Posto Indígena Pindaré (FUNAI Post - Guajajara Indians), along rio Pindaré, ca. $15 \mathrm{~km} \mathrm{~W}$ of Santa Inês, 03³0'S, 45³0'W, 03.IX.1983, fr., M.J. Balick et al. 1556 (CEN, MG, NY, SP); Colinas, Fazenda da Ana, antes do povoado Laranjal, 0559'S, 44²2'W, 13.III.2016, fr., G.P. Lima 621 (MAR); Governador Archer, 05¹3'27'S, 4406'00"W, 04.VIII.2017, fr., K.F. Silva 382 (UB); Peritoró, BR 135, próximo à fábrica de cimento, $04^{\circ} 22^{\prime} \mathrm{S}$,

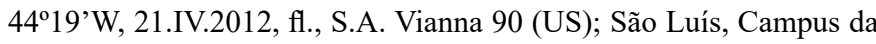
UFMA, $02^{\circ} 33^{\prime}$ S, $44^{\circ} 18^{\prime}$ W, 10.IV.2017, fr., G.P. Lima 649 (MAR) and 650 (MAR).

2. Allagoptera leucocalyx (Drude) Kuntze, Revis. Gen. Pl. 2: 726. 1891. Figure 1e-g.

Solitary palm with $1-1.5 \mathrm{~m}$ tall that is characterized by the acaulescent habit, unbranched inflorescence, and absence of spines. This palm can be confused with Syagrus glazioviana but is distinguished by its unbranched inflorescence with densely clustered flowers and by its ramentas over the central vein on the abaxial surface of the middle pinnae.

Common names: coco-da-chapada, ariri, coco-da-vassoura, guriri, licuri, and licuri-da-mata.

Distribution and ecology: It occurs in Brazil (Bahia, Goiás, Mato Grosso, Mato Grosso do Sul, Minas Gerais, Paraná, and Piauí), as well as the northern Argentina, Bolivia and Paraguay (Moraes 1996, Flora do Brasil 2020 under construction), growing mainly in gallery forests of the Cerrado biome (Martins et al. 2015). According to this research, it is possible to see that the species distribution zone is expanded to the Maranhão Cerrado, in sites located near the borders of the state of Tocantins (Figure 2a). The specimens were collected with flowers in December and fruits in December and March.
Conservation: Allagoptera leucocalyx existing data are inadequate to assess the species' risk of extinction through criteria B1 since it has less than three single records of occurrence. Thus, considering that and following IUCN (2012) criteria, we propose to list this taxon under the Data Deficient (DD) category for Maranhão. In addition, we highlight that more field surveys are urgently needed in order to obtain more information.

Material examined: BRAZIL, MARANHÃO: Estreito, BR-010, entre Estreito e Carolina, 06050'18”S, 47 26’32”W, 11.XII.2014, fl. and fr., M.M. Toledo \& M.M. Cavallari 12 (CEN); Estreito, canteiro de obras do UHE Estreito, 06 34'51'S, 47²7'39”W, 11.III.2007, fr., G. Pereira-Silva \& G.A. Moreira 11367 (CEN).

3. Astrocaryum campestre Mart., Hist. Nat. Palm. 2: 79. 1824. Figure 3a-c.

Solitary or clustered palm with $0.5-1.5 \mathrm{~m}$ tall that is characterized by the acaulescent habit and the inflorescence near ground level when compared to the species Astrocaryum gynacanthum and Astrocaryum vulgare.

Common names: tucum-rasteiro, tucum-da-chapada, tucum, and jarivá.

Distribution and ecology: This species is present in the central region of Brazil (Bahia, Goiás, Maranhão, Mato Grosso, Minas Gerais, Pará, Piauí, and Tocantins) and east of Bolivia (Kanh 2008, Flora do Brasil 2020 under construction). It usually grows in cerrado stricto sensu on deep sandy soils (Henderson et al. 1995). In Maranhão, specimens were collected in the open formations of the Cerrado biome in the south and southwest regions of the State (Figure 2a), with flowers from December to March and fruits mainly from February to October.

Conservation: Astrocaryum campestre has an EOO of 30,655.591 $\mathrm{km}^{2}$, which approaches the minimum threshold for the threat category $\left(\mathrm{EOO}<20,000 \mathrm{~km}^{2}\right)$, and is registered in only nine locations in the south of the State. Although there are examples of populations recorded within the boundaries of the Mirador State Park and the Chapada das Mesas National Park, it should be emphasized that outside protected areas the habitat of this palm is suffering high anthropic pressure by the advance of mechanized agriculture (Barreto et al. 2012). Given this information and following the IUCN (2012) recommendations, we propose the category of Near Threatened (NT) for this species in Maranhão.

Material examined: BRAZIL, MARANHÃO: Balsas, Projeto Geral de Balsas - Lote 23, 07³5'S, 46 $05^{\circ}$ 'W, 21.III.1997, fl. and fr., R.C. Oliveira et al. 617 (HEPH); Balsas, Agrovila Nova de Carli lote 23, 08³7'20"S, 4644'21'”, 04.VII.1998, fr., R.C. Oliveira et al. $1234(\mathrm{HEPH})$; Carolina, transect area 3, near Pedra Caída on the Carolina-Estreito road, $07^{\circ} 02^{\prime}$ S, $47^{\circ} 27^{\prime}$ W, 03.VII.1993, fr., J.A. Ratter et al. 6722 (UB); Carolina, Parque Nacional da Chapadas das Mesas, acesso no km 596 da BR-230, 0707'33'S, 47²2'13”W, 12.IV.2014, fr., M.F. Simon et al. 2902 (CEN); Estreito, road between Estreito and Carolina, $23 \mathrm{~km}$ south of Estreito, 06 $6^{\circ} 45^{\prime} \mathrm{S}, 47^{\circ} 20^{\prime} \mathrm{W}, 01 . X I I .1981$, fl., J. Jangoux et al. 1773 (MG); Grajaú, on road from Porto Franco, 64 km from Grajaú, 0545'S, 46³0'W, 23.XI.1993, fr., M.J. Balick et al. 3721 (CEN); Mirador, Parque Estadual do Mirador, base Geraldina,

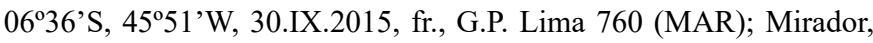
Parque Estadual do Mirador, base Geraldina, 14.II.2017, fr., A.W.C. Ferreira s.n. (MAR); Mirador, Parque Estadual do Mirador, localidade Cachoeira, 24.IX.1988, fr., F. Norberto et al. 113 (SLUI); Porto Franco, 

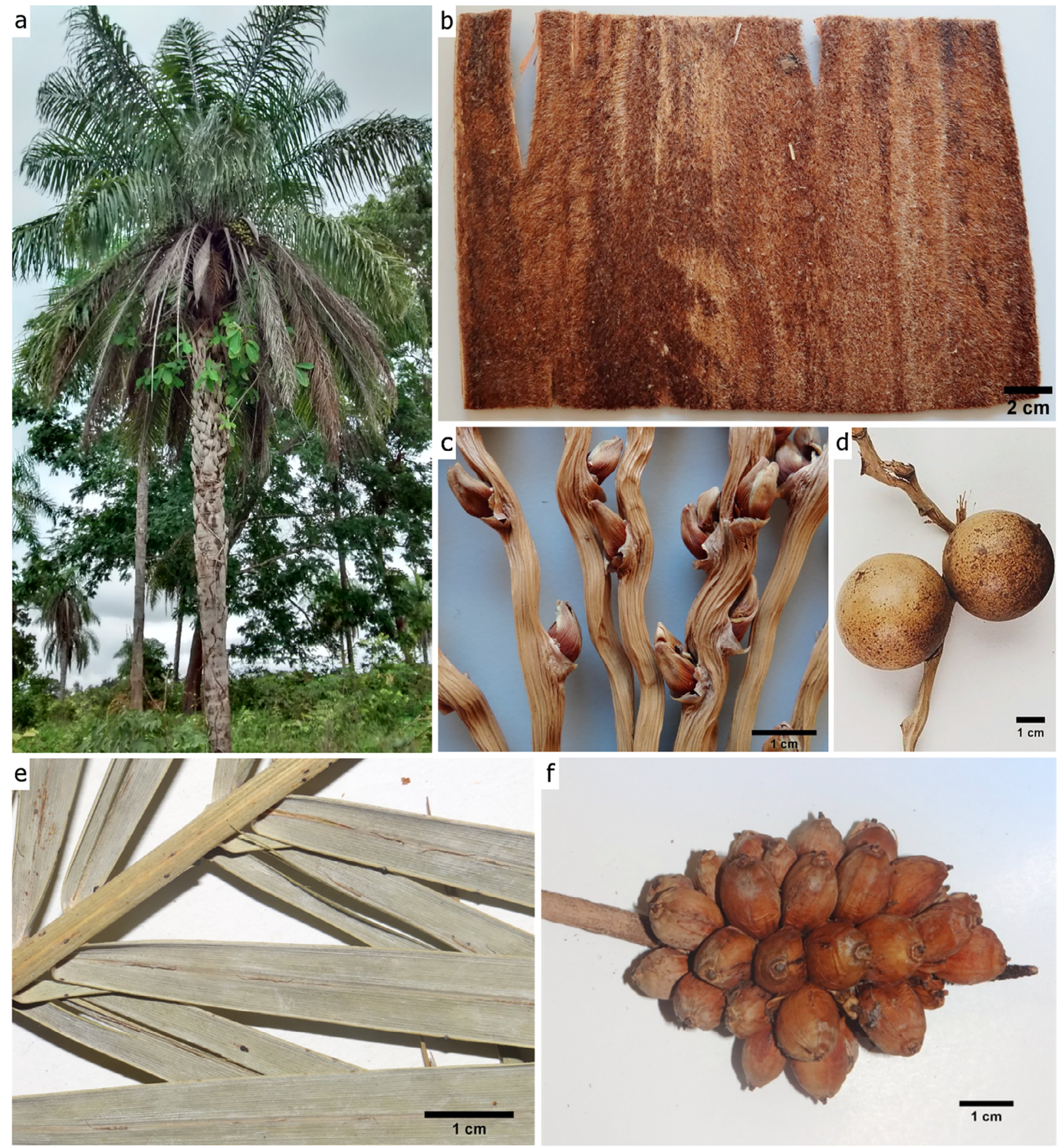

g

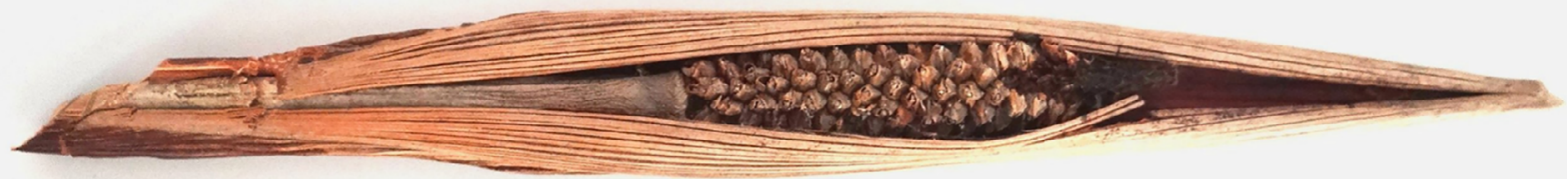

Figure 1. a-d. Acrocomia aculeata; a. palm with stem covered with remnants leaf sheaths (G.P. Lima 621); b. peduncular bract externally covered with velutinous brownish indument (E.L. Perez et al. 2063); c. pistillate flowers (E.L. Perez et al. 2062); d. fruits (E.L. Perez et al. 1901). e-g. Allagoptera leucocalyx; e. presence of ramentas over the central vein on the abaxial surface of the middle pinnae (R.C. Martins et al. 1061); f. fruits (M.J. Balick et al. 3715); g. unbranched inflorescence with densely clustered flowers (M.M. Toledo \& M.M. Cavallari 12). 


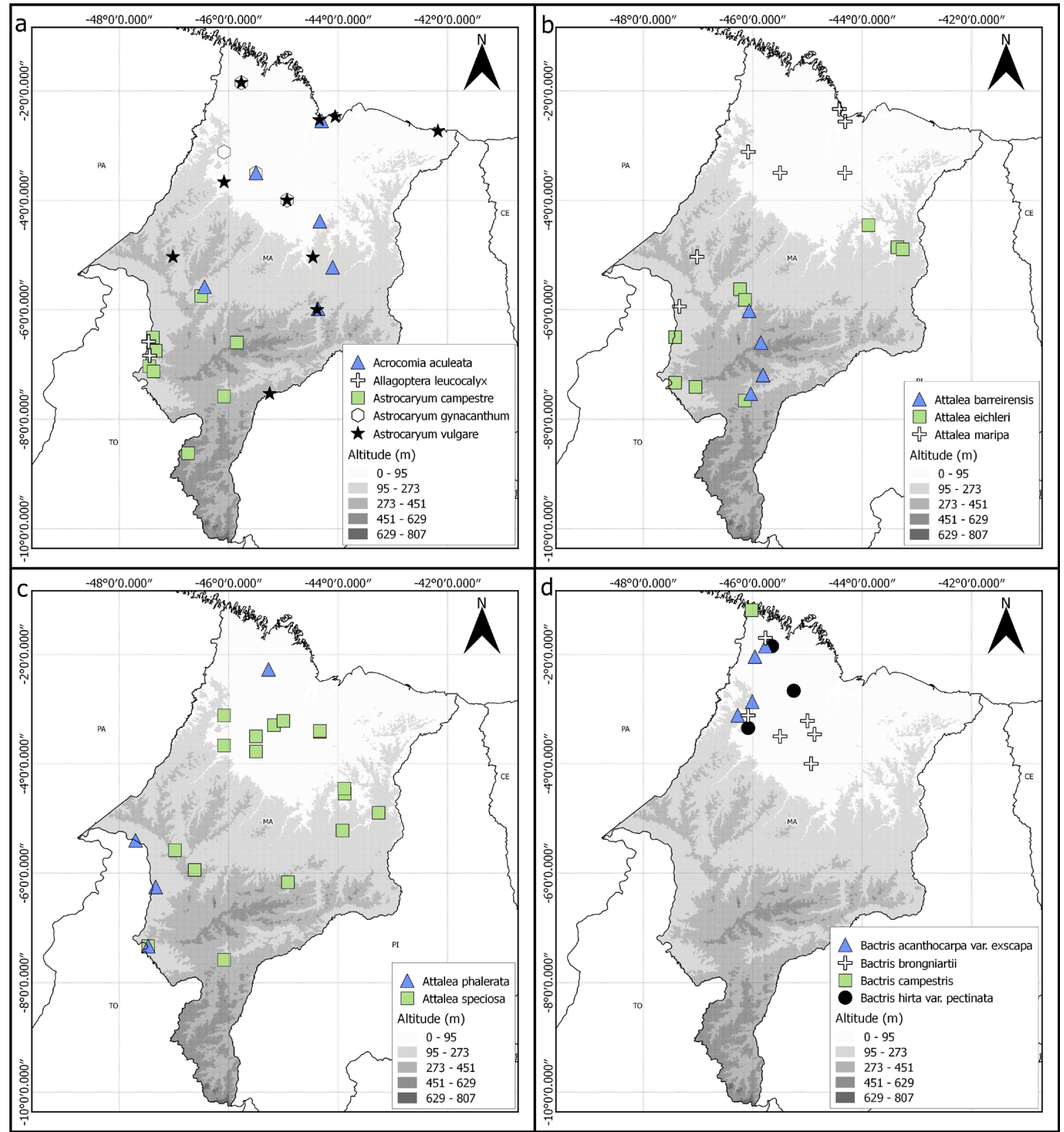

Figure 2. a. Distribution maps of Acrocomia aculeata, Allagoptera leucocalyx, Astrocaryum campestre, Astrocaryum gynacanthum, and Astrocaryum vulgare. b. Distribution maps of Attalea barreirensis, Attalea eichleri, and Attalea maripa. c. Distribution maps of Attalea phalerata and Attalea speciosa. d. Distribution maps of Bactris acanthocarpa var. exscapa, Bactris brongniartii, Bactris campestris, and Bactris hirta var. pectinata. Source: prepared by the authors.

Belém-Brasília Highway, 10 km N of Estreito, 01.XII.1981, fr., M.J. Balick et al. 1315 (CEN, NY).

4. Astrocaryum gynacanthum Mart., Hist. Nat. Palm. 2: 73. 1824. Figure 3d-g.

Solitary or clustered, caulescent palm with $3.5-9 \mathrm{~m}$ tall that is distinguished by its pistillate flowers covered with black spines and fruits with epicarp that splits at maturity.
Common names: mumbaca, marajú, marayua (Guajajara), ju and jupihu (Ka'apor), yu-’y (Guajá), marajá, marajá-açú, and mumbaca-dapreta.

Distribution and ecology: It is widespread in the Amazon, with confirmed records for Bolivia, Peru, Colombia, Venezuela, Guianas, and Brazil (Kahn 2008), generally found in the terra firme forests (Lorenzi et al. 2010). In Brazil, it occurs in the states of Acre, Amazonas, Amapá, Maranhão, Mato Grosso, Pará, Rondônia, and Roraima (Flora do Brasil 2020 under construction). In Maranhão, this species was collected in the northwest region (Figure 2a), with flowers in May, August, and November. 

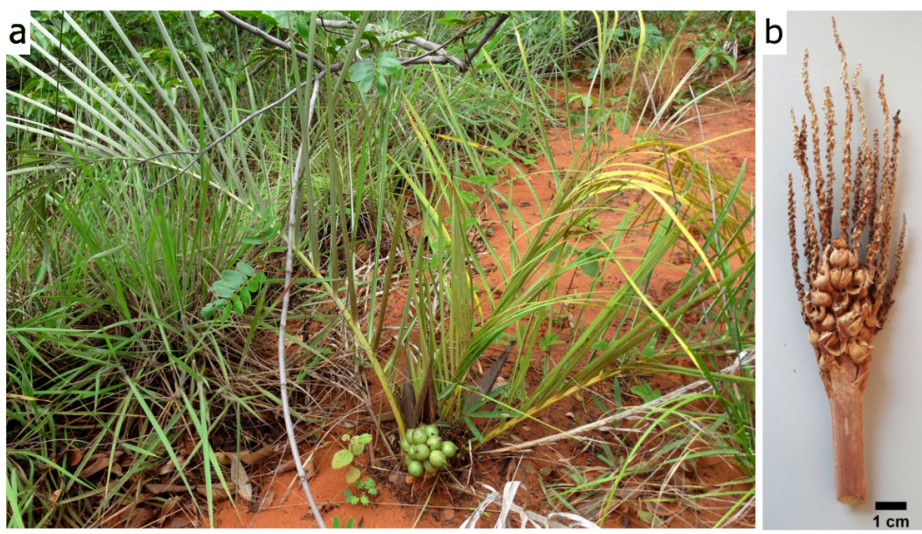

d

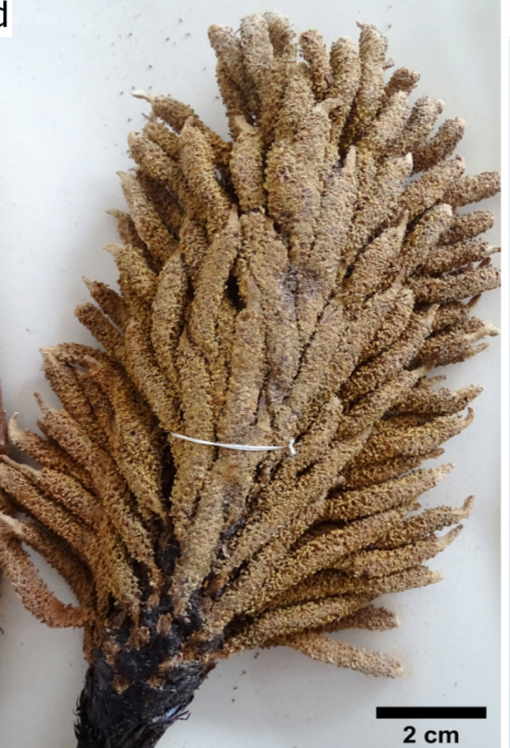

$\mathrm{h}$

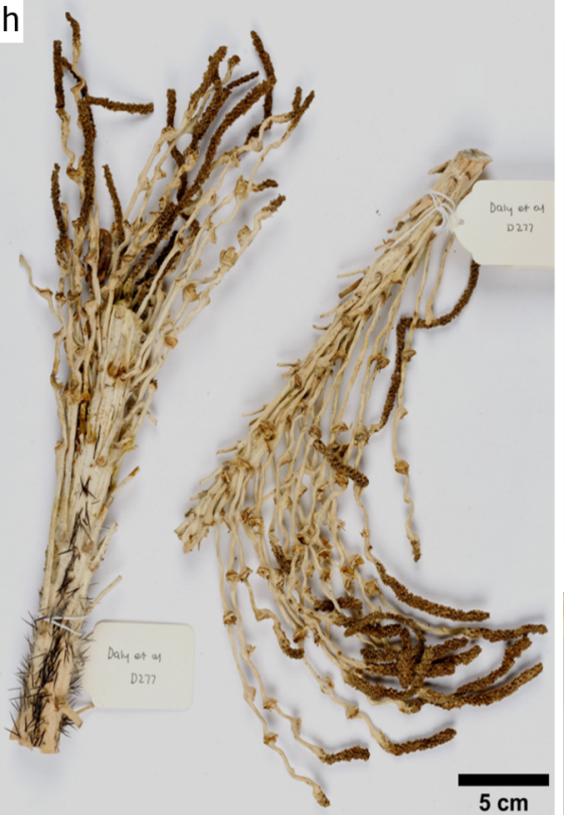

e
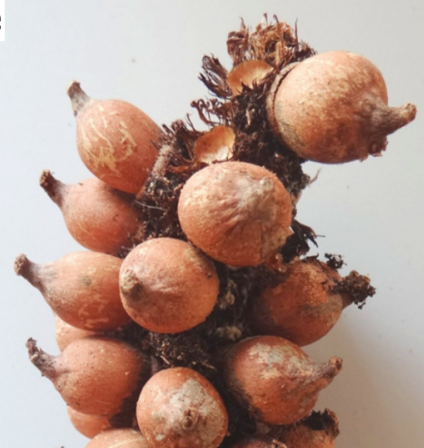

5
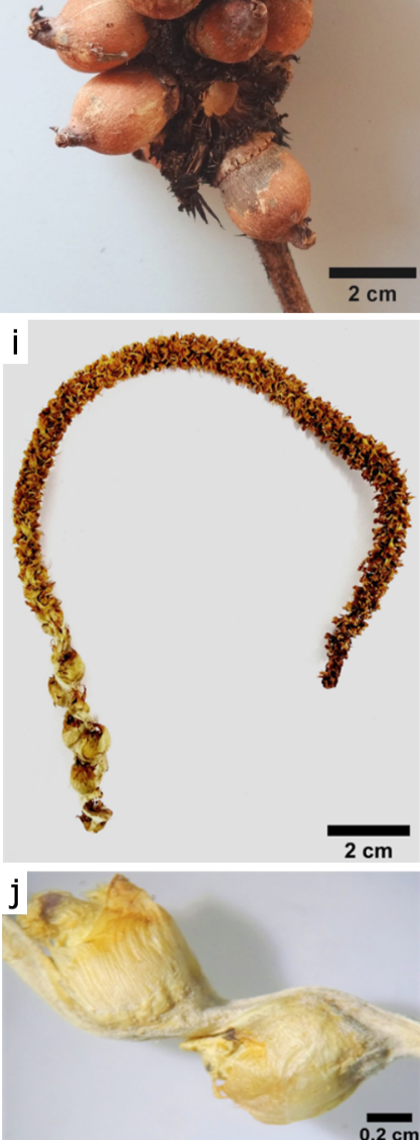

f

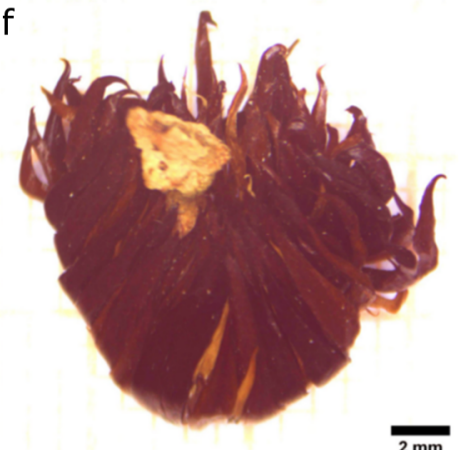

g
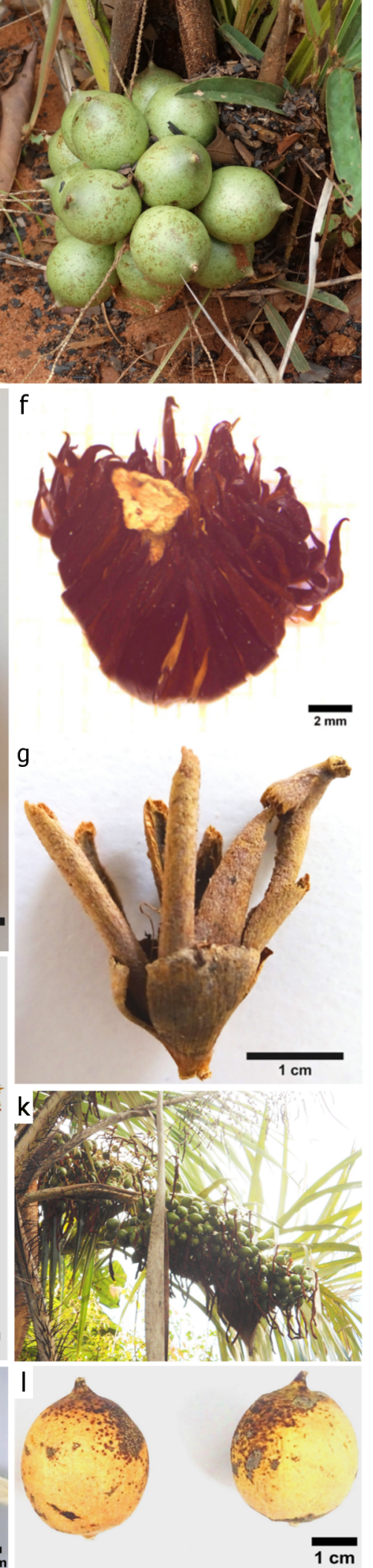

Figure 3. a-c. Astrocaryum campestre; a. palm with acaulescent habit (A.W.C. Ferreira s.n.); b. inflorescence (G. Pereira-Silva et al. 9694); c. infructescence supported near ground level (A.W.C. Ferreira s.n.). d-g. Astrocaryum gynacanthum; d. inflorescence (M. Kuhlmann \& S. Jimbo 70); e. infructescence (E.A. Santos \& O.S. Pereira 66); f. pistillate flower covered with black spines (W.L. Balée \& B.G. Ribeiro 1672); g. fruit with epicarp splits at maturity (M. Nee 34767). h-l. Astrocaryum vulgare; h. inflorescence (D.C. Daly et al. 277); i. rachilla (G.P. Lima 657); j. unarmed pistillate flowers (G.P. Lima 657); k. infructescence (G.P. Lima 501); 1. fruits (G.P. Lima 656). 
Conservation: Astrocaryum gynacanthum is assessed as Vulnerable [VU B1ab(iii)] according to the IUCN (2012) criteria since it has an EOO of $10,742.057 \mathrm{~km}^{2}$ and it is known in only four different locations in Maranhão. Moreover, the habitat of this species shows a marked decline in its extension and also in its quality, due to the intense deforestation observed in the Maranhão Amazon in the last decades (Celentano et al. 2017).

Material examined: BRAZIL, MARANHÃO: Bom Jardim, Posto Indígena Pindaré (FUNAI Post - Guajajara Indians), along rio Pindaré, ca. $15 \mathrm{~km} \mathrm{~W}$ of Santa Inês, $03^{\circ} 30^{\prime}$ 'S, 45³0'W, 31.VIII.1983, fl., M.J. Balick et al. 1479 (CEN, MG, SP); Cândido Mendes, fragmento de floresta amazônica da Fazenda Sete Irmãos, 01 51'13”'S, 4546'13.2”W, 03.XI.2017, fl., G.P. Lima et al. 666 (MAR); Lago Verde, Fazenda São Francisco, estrada entre Alto Alegre - Lago Verde, km 9, 26.III.1985, st., A.B. Anderson et al. 2183 (MG); Ka'apor Indian Reserve, 9.V.1986, fl., W. Balée 2251 (NY).

5. Astrocaryum vulgare Mart., Hist. Nat. Palm. 2: 74. 1824. Figure 3h-1. Solitary or clustered palm with $1.8-20 \mathrm{~m}$ tall that differs from Astrocaryum campestre by the caulescent habit. It can be distinguished from Astrocaryum gynacanthum by its proximal rachillae that reach almost $30 \mathrm{~cm}$ in length (vs. $<10 \mathrm{~cm}$ in $A$. gynacanthum), by the unarmed pistillate flowers and fruits not splitting at maturity.

Common names: tucum, tucumã, takamã (Guajá), tukumã'y (Ka'apor), tucum-bravo, tucum-piranga, and tucumã-do-pará.

Distribution and ecology: This taxon is distributed in Venezuela, Guianas, and Brazil (Amapá, Goiás, Maranhão, Pará, Piauí, and Tocantins) and occurs in secondary vegetation or open areas, especially on sandy soils (Kahn 2008, Lorenzi et al. 2010). In Maranhão, it was found north to south (Figure 2a), mainly in secondary vegetations and restingas, with flowers from May to July and fruits from July to March. According to Oliveira et al. (2003), flowering and fruiting events occurring all year long, but the peaks occur at different times. The flowering peaks occurs between March and July, and the fruiting peaks from December to March.

Conservation: Following the IUCN (2012) criteria, this species is considered as Least Concern (LC) for Maranhão since it has a large EOO $\left(176,276.369 \mathrm{~km}^{2}\right)$.

Material examined: BRAZIL, MARANHÃO: Açailândia, 4 km $\mathrm{S}$ of the city on a side road, $05^{\circ} 02^{\prime} \mathrm{S}, 47^{\circ} 01^{\prime} \mathrm{W}, 6 . \mathrm{IX} .1994$, fr., L.R. Noblick \& J.A. Feitosa 4972 (IPA, NY); Barreirinhas, 245'00.0”S, 4247'59.0”W, 25.VI.2012, fl., S.M. Santos s.n. (MAR); Bom Jardim, Posto Indígena Carú (FUNAI Post - Guajajara Indians), along rio Pindaré

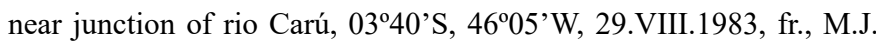
Balick et al. 1475 (MG, NY, SP); Cândido Mendes, campo próximo da sede da Fazenda Sete Irmãos, 0151'30.9”S, 4548'13.7'W, 04.XI.2017, fr., G.P. Lima et al. 676 (MAR); Colinas, próximo ao povoado Laranjal, às margens do rio Alpercatas, $06^{\circ} 00^{\prime} \mathrm{S}, 4^{\circ} 23^{\prime} \mathrm{W}$, 14.III.2016, fr., G.P. Lima 626 (MAR); Dom Pedro, 0502'24”S, 44²7'36”W, 07.VII.2017, fr., K.F. Silva 248 (UB); Lago Verde, Fazenda São Francisco, 11 km

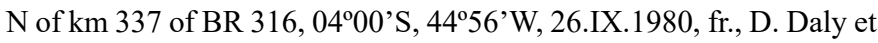
al. 277 (MG, NY); Loreto, "Ilha de Balsas" region, shore of Parnaíba River, opposite city of Ribeiro Gonçalves, $07^{\circ} 32^{\prime}$ 'S, $45^{\circ} 15^{\prime}$ 'W, 3.IX.1963, fr., G. Eiten \& L.T. Eiten 5453 (SP); São José de Ribamar, Praia de Panaquatira, 02²8'23.0”S, 4403'13.8'W, 16.XI.2014, fr., G.P. Lima 501 (MAR); São José de Ribamar, Praia de Panaquatira, 02²8’23.0”S,
4403'13.8”W, 29.V.2017, fl., Lima, G.P 657 (MAR); São Luís, Praia da Guia, 02³1'56”S, 44²0’25”W, 17.II.2016, fr., G.P. Lima 656 (MAR).

6. Attalea barreirensis Glassman, Illinois Biol. Monogr. 59: 25-27. 1999. Figure 4a-e.

Solitary palm with 1.5-2.3 m tall that can be confused with Attalea eichleri by the acaulescent habit. Nevertheless, it can be differentiated by having rachillae of the staminate and androgynous inflorescences spirally arranged around the rachis, staminate flowers visibly arranged in two rows on the rachilla, stamens with straight anthers, and fruits with only one seed.

Common names: coco-de-um-caroço-só, coco-cunhã, catolé, and piaçaba.

Distribution and ecology: It is endemic in Brazil found in the cerrado stricto sensu of Bahia, Goiás, Piauí, and Tocantins states, generally at altitudes between 600 and $800 \mathrm{~m}$ (Glassman 1999, Lorenzi et al. 2010, Flora do Brasil 2020 under construction). According to this research, the geographical distribution of Attalea barreirensis is expanded to the Maranhão Cerrado, with specimens in the Mirador State Park and other areas surrounding this conservation unit (Figure 2b). It was collected with flowers in March and fruits in August, December, and February.

Conservation: $A$. barreirensis is assessed as Endangered (EN $\mathrm{B} 1 \mathrm{ab}[\mathrm{iii}]$ ) for Maranhão since it has an EOO of 2,818.143 $\mathrm{km}^{2}$ and has only five records in different locations. Only two of the samples were cataloged within the Mirador State Park boundary, and the other specimens were collected in other areas of Cerrado, which exhibit a marked decline in their extension due to the planintg of several soybean crops (Barreto et al. 2012). In the national context, A. barreirensis is considered as Vulnerable (VU), because its region of occurrence coincides in large part with the areas that are currently among the most affected by the agricultural expansion in the Cerrado (CNCFLORA 2019).

Material examined: BRAZIL, MARANHÃO: Balsas, condomínio Kissy, lote 23, 07.III.1996, fl., G. Pereira-Silva et al. 3432 (CEN); Grajaú, entre Grajaú e Formosa da Serra Negra (MA-06), 0601'02”S, 4603'54"W, 09.XII.2014, fr., M.M. Toledo \& M.M. Cavallari 08 (CEN); Mirador, Parque Estadual do Mirador, localidade Cágados a 50 $\mathrm{m}$ de Cachoeira, 28.II.1989, fr., F. Noberto et al. 151 (SLUI); Mirador, Parque Estadual do Mirador, Base Geraldina, 30.VIII.2015, fr., A.N.F. Silva 648 (MAR); São Raimundo das Manguabeiras, próximo à BR230, 07¹1'33”S, 4548'41'W, 11.XII.2014, fr., M.M. Toledo \& M.M. Cavallari 6 (CEN); São Raimundo das Manguabeiras, próximo à BR230, 07¹1'32”S, 4548'40”W, 11.XII.2014, fr., M.M. Toledo \& M.M. Cavallari 10 (CEN).

7. Attalea eichleri (Drude) A.J.Hend., Palms Amazon: 143.1995. Figure 4f-j.

Attalea eichleri is a solitary palm with $1-2.5 \mathrm{~m}$ tall. As previously highlighted, this species can be confused with Attalea barreirensis by the acaulescent habit. However, the following set of characters can distinguish this species: rachillae of the staminate and androgynous inflorescences arranged on only one side of the rachis, staminate flowers visibly arranged on only one side of the rachilla, stamens with spirally twisted and coiled anthers, and fruits with three or more seeds.

Common names: piaçava, piaçaba, coco-curúa, and pindoba. 

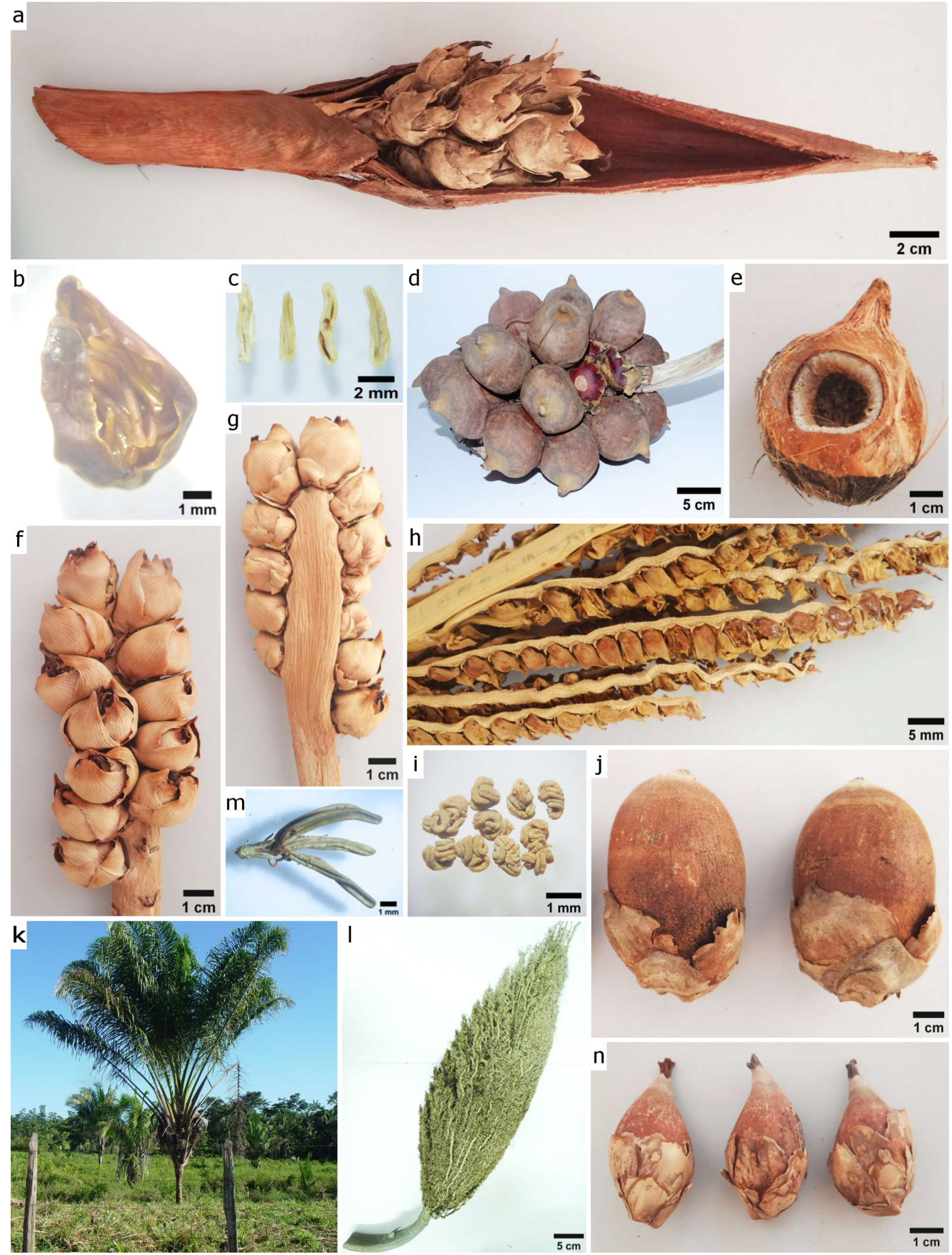

Figure 4. a-e. Attalea barreirensis; a. androgynous inflorescence (G. Pereira-Silva et al. 3432); b. staminate flower with no exserted stamens (G. Pereira-Silva et al. 3432); c. straight anthers (G. Pereira-Silva et al. 3432); d. infructescence with fruits arranged around the rachis (A.N.F. Silva 648); e. fruit with one seed (M.M. Toledo \& M.M. Cavallari 10); f-j. Attalea eichleri; f. side of the androgynous inflorescence with flowers (G. Pereira-Silva et al. 10494); g. side of the androgynous inflorescence devoid of flowers (G. Pereira-Silva et al. 10494); h. staminate flowers arranged only in one row on the rachillae of the staminate inflorescence (M.J. Balick et al. 1559); i. spirally twisted and coiled anthers (M.J. Balick et al. 1559); j. fruits (M.M. Toledo \& M.M. Cavallari 02). k-n. Attalea maripa; k. palm with the leafs spirally arranged and organized in rows; 1. staminate inflorescence (G.P. Lima 648); m. staminate flower with stamens longer than the petals (G.P. Lima 648); n. fruits (M.J. Balick et al. 1302). 
Distribution and ecology: This species occurs in Brazil (Bahia, Goiás, Maranhão, Mato Grosso, Pará, Piauí, and Tocantins) and Bolivia, usually growing in transition zones between forests and savannas, in seasonally dry areas (Henderson et al. 1995, Pinheiro 2011, Flora do Brasil 2020 under construction). It was collected in the southwest of Maranhão, and some specimens were also collected in the eastern region, near to the borders of the state of Piauí (Figure 2b). The flowering was recorded between September and December and the fruiting from November to December.

Conservation: A. eichleri is classified as Least Concern (LC) since it has an EOO of 70,775.480 $\mathrm{km}^{2}$ in Maranhão.

Material examined: BRAZIL, MARANHÃO: Balsas, Santa Luzia, próximo ao rio Balsas, 07³9'33’S, 4608'37’'W, 11.XII.2014, fr., M.M. Toledo \& M.M. Cavallari 02 (CEN); Carolina, ca. 8 km E de Carolina na Rodovia Transamazônica, 07²0’S, 47²5’W, 02.XII.1981, fr., M.J. Balick et al. 1317 (CEN, MG, NY); Carolina, between Carolina e Estreito, 21.XI.1984, fl., M.J. Balick et al. 1675 (NY); Carolina, Ilha dos Botes, a duas léguas de Carolina, 30.VIII.1949, fr., J.M. Pires \& G.A. Black 1575 (US); Caxias, 01.X.1952, fl., G. Bondar s.n. (RB); Caxias, 16.XII.1958, fl., W.A. Egler 747 (MG); Caxias, próximo a BR-

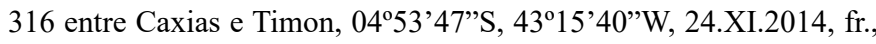
M.M. Cavallari \& M.M. Toledo 39 (CEN); Codó, localidade Mirindiba, estrada vicinal de acesso à fazenda Canto da Roça, 15.XII.1989, fl., C.U.B. Pinheiro et al. 89-10 (CEN); Grajaú, Chácara Fortaleza, 05³7'30”'S, 46¹3'58”'W, 08.XII.2014, fr., M.M. Toledo \& M.M. Cavallari 01 (CEN); Grajaú, entre Grajaú e Formosa da Serra Negra (MA-06), 08.XII.2014, fl. and fr., M.M. Toledo \& M.M. Cavallari 07 (CEN); Mirador, Parque Estadual do Mirador, Varjão, 20.IX.1988, fl., F. Noberto 97 (MG, SLUI); Porto Franco, Belém-Brasília highway, 10 km N of Estreito do Goiás, 06³0'S, 47²5'W, 01.XII.1981, fl. and fr., M.J. Balick et al. 1313 (CEN, MG, NY); Porto Franco, ca. 20 km N of Estreito de Goiás on Belém-Brasília highway, 06³0'S, 47²5' W, 02.XII.1981, fl., M.J. Balick et al. 1316 (CEN, MG, NY); Riachão, BR230, entre Carolina e Riachão, 07²4’40”S, 4702'45”W, 10.XII.2014, fr., M.M. Toledo \& M.M. Cavallari 09 (CEN).

8. Attalea maripa (Aubl.) Mart., Voy. Amér. Mér. 7(3): 123. 1844. Figure 4k-n.

Solitary and caulescent palm with 5-25 $\mathrm{m}$ tall that is recognized by the leaves spirally arranged around the stem, visibly organized in five or six rows and also by the stamens longer than the petals. The other caulescent species of Attalea have anthers shorter than the petals, that do not protrude from flowers.

Common names: anajá, inajá, inajaí, inaja-'y (Guajá), and inaza (Guajajara).

Distribution and ecology: Attalea maripa is widespread from northern South America to the eastern Andes, that is, in Bolivia, Ecuador, Colombia, Venezuela, Trinidad and Tobago, Guianas, and Brazil (Henderson et al. 1995). In Brazil, it occurs in the states of Acre, Amazonas, Maranhão, Mato Grosso, Mato Grosso do Sul, Pará, and Rondônia, in terra firme forests and in open areas that have suffered impacts (Henderson et al. 1995, Glassman 1999, Lorenzi et al. 2010, Flora do Brasil 2020 under construction). In Maranhão, it was found in areas of influence of the Amazon biome in the north, northwest, and southwest regions (Figure 2b), with flowering peaks from April to September and fruiting from April to December. Pires et al. (2016), reported flowering and fruiting all year round, being these long-lasting events.

Conservation: According to IUCN (2012) criteria, this species is categorized as Least Concern (LC) for Maranhão since it has an EOO of $48,432.198 \mathrm{~km}^{2}$.

Material examined: BRAZIL, MARANHÃO: Açailândia, Fazenda Itabaiana (Companhia Vale do Rio Doce), ca. $17 \mathrm{~km} \mathrm{~S}$ on

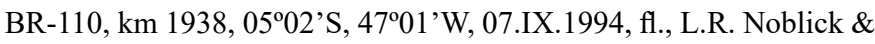
J.A. Feitosa 4973 (IPA, NY); Alcântara, sub-bacia dos rios Pepital e Grande, $02^{\circ} 20^{\prime} 00^{\prime}$ 'S, 44²5'00”W, 11.XI.2012, fr., E.C.M. Oliveira s.n. (MAR); Bom Jardim, Posto Indígena Pindaré (FUNAI Post - Guajajara Indians), along rio Pindaré, ca. $15 \mathrm{~km} \mathrm{~W}$ of Santa Inês, $03^{\circ} 30^{\prime} \mathrm{S}$, 45³0'W, 03.IX.1983, fl., M.J. Balick et al. 1555 (CEN, MG, NY); Itapecuru-Mirim, localidade Moreira, próximo à Fazenda do Sr. José Mário Frazão, fr., 16.XII.1989, C.U.B. Pinheiro \& A. Araújo Neto 89-13 (CEN, NY); Nova Olinda do Maranhão, P.I. Guajá, rio Turiaçu, Guajá Indians, $03^{\circ} 07^{\prime}$ S, $46^{\circ} 05^{\prime} \mathrm{W}, 18$.VI.1987, fl., W. Balée 3377 (NY); São

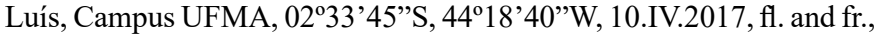
G.P. Lima 647 (MAR) and 648 (MAR); Ribamar Fiquene, 0556'24”S, 47²0'24’'W, 25.VII.2017, fr., C.A. Sousa 405 (UB).

9. Attalea phalerata Mart. ex Spreng., Syst. Veg. (ed.16) [Sprengel] 2: 624. 1825. Figure 5a-d.

Solitary and caulescent palm with up $5 \mathrm{~m}$ tall recognized by its aerial stem fully covered with remnants leaf sheaths, staminate flowers with linear petals less than $1 \mathrm{~mm}$ wide, and straight anther that do not protrude from flowers.

Common names: paxiba, acuri, bacuri, pirinã, and urucuri.

Distribution and ecology: Attalea phalerata occurs in Peru, Bolivia, Paraguay, and Brazil (Henderson et al. 1995). In Brazil, this species is found in the Amazon and Cerrado phytogeographic dominions, in the states of Acre, Goiás, Mato Grosso, Mato Grosso do Sul, Minas Gerais, Pará, Rondônia, São Paulo, and Tocantins, as well as the Distrito Federal (Lorenzi et al. 2010, Flora do Brasil 2020 under construction). According to this research, the distribution area is expanded to the southwest Maranhão near the Tocantins River region, and also to flooded areas of the Baixada Maranhense in the north portion (Figure 2c). The specimens were collected with flowers in May and fruits in July and November. According to Fava et al. (2011), the flowering occurs continuously during the whole year in Pantanal.

Conservation: According to IUCN (2012) criteria, A. phalerata is assessed as Least Concern (LC) for Maranhão, given the Extent of Occurrence (EOO) of $30,855.775 \mathrm{~km}^{2}$. Probably, the EOO is even larger than the reported in this analysis, since the records of the taxon are still scarce and distributed irregularly in the State territory. The classification according to IUCN (2012) agrees with the national classification of CNCFLORA (2019), in which this taxon is considered as Least Concern (LC), due to its wide geographical distribution in Brazil.

Material examined: BRAZIL, MARANHÃO: Carolina, campo duas léguas abaixo de Carolina, rio Tocantins, 29.V.1950, fl., J.M. Pires \& G.A. Black 2493 (IAN); Imperatriz, 05²3'59'S, 4742'00'W, 12.VII.2017, fr., C.A. Sousa 280 (UB); Porto Franco, $15 \mathrm{~km}$ from Porto Franco, on road to Grajaú, 06¹5'S, 47²0'W, 23.XI.1993, fr., M.J. Balick et al. 3720 (CEN); Santa Helena, entre os povoados Mangabeira e Queimadas, 02 ${ }^{\circ} 16^{\prime} 35.4^{\prime \prime S}$, 45¹6'15.0”W, 05.XI.2017, fr., G.P. Lima et al. 680 (MAR). 
10. Attalea speciosa Mart. ex Spreng., Syst. Veg. (ed.16) [Sprengel] 2: 624. 1825. Figure 5e-h.

Solitary and caulescent palm with 5-24 $\mathrm{m}$ tall that is characterized by its middle pinnae always distributed regularly and arranged in the same plane along the rachis. The other species of the genus Attalea exhibit middle pinnae distributed in groups and/or arranged in different planes.

Common names: babaçu, jetahu-'y (Ka'apor), uauassu and wa-'y (Guajá), baguaçu, and guaguaçu.

Distribution and ecology: Attalea speciosa occurs in Bolivia, Guianas, and Brazil (Acre, Amazonas, Bahia, Ceará, Goiás, Maranhão, Mato Grosso, Pará, Pernambuco, Piauí, Rondônia, and Tocantins), growing mainly in terra firme forests, savannas, and disturbed areas on well-drained soils (Lorenzi et al. 2010, Flora do Brasil 2020 under construction). According to data from the MCI/STI (1982), approximately $60 \%$ of the area of occurrence of this species is concentrated in Maranhão, in which it develops dense populations. In Maranhao, the specimens were obtained mainly in the north, central and eastern regions (Figure 2c), with flowers between September and December, and fruits from July to December. As stated by Anderson et al. (1988), in a research carried out in the region of the Mearim Valley, flowering occurs more intensely in the rainy season (January to July) and the fruiting in the dry season (September to January).

Conservation: According to IUCN (2012) criteria, this species is considered as Least Concern (LC) since it has an EOO of $133,880.989 \mathrm{~km}^{2}$.

Material examined: BRAZIL, MARANHÃO: Bom Jardim, Posto Indígena Pindaré (FUNAI Post - Guajajara Indians), along rio Pindaré, ca. $15 \mathrm{~km}$ W of Santa Inês, 03³0'S, 45³0'W, 01.IX.1983, fl., M.J. Balick et al. 1528 (CEN, MG, NY, SP); Bom Jardim, Posto Indígena Carú (FUNAI Post - Guajajara Indians), along rio Pindaré near junction of rio Carú, 0340'S, 4605'W, 28.VIII.1983, fr., M.J. Balick et al. 1468 (CEN, NY); Buritirana, 05³4'48'S, 4658'48'W, 06.VII.2017, fr., C.A. Sousa 253 (UB); Carolina, between the towns of Carolina and Estreito, 22.XI.1984, fl. and fr., M.J. Balick et al. 1677 (CEN, NY); Caxias, próximo a BR-316 entre Caxias e Timom, 0453'42”S, 4315'40”W, 24.XI.2014, fl. and fr., M.M. Cavallari \& M.M. Toledo 38 (CEN); Codó, localidade Bacabinha, estrada vicinal de acesso à Fazenda Canto da Roça, 15.XII.1989, fr., C.U.B. Pinheiro et al. 89-11 (CEN, NY); Codó, Comunidade Santo Antônio dos Pretos, 13.VIII.2009, fr., D.S. Santos \& M.C.L. Barbosa s.n. (SLUI); Fernando Falcão, village of Leandro, ca. $120 \mathrm{~km}$ from city of Barra do Corda, 06 ${ }^{\circ} 10^{\prime}$ 'S, 44 $4^{\circ} 55^{\prime} \mathrm{W}, 25 . \mathrm{XI} .1993$, fl. and fr., M.J. Balick et al. 3732 (CEN); Itapecuru-Mirim, on-farm

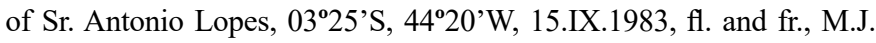
Balick et al. 1627 (CEN); Itapecuru-Mirim, estrada vicinal, localidade denominada Escondido, 16.XII.1989, st., C.U.B. Pinheiro \& A. Araujo Neto 89-17 (CEN); Penalva, 21.VIII.2009, fr., D.S. Santos s.n. (SLUI); P.I. Guajá (Terra Indígena Alto Turiaçu), rio Turiaçu, Guajá Indians, 0307’'S, 4605’W, 18.VI.1987, fr., W.L. Balée 3376 (NY); São Félix de Balsas, community know as "Poço", 07³5'S, 4605’W, 04.XII.1981, fl. and fr., M.J. Balick et al. 1342 (CEN, MG, NY); Santa Inês, Fazenda Agropecuária Muniz, 0346’37.72”S, 45²9'55.84”W, 13.XI.2014, fl. and fr., M.M. Cavallari \& M.M. Toledo 35 (CEN); Senador Alexandre Costa, 05¹3'12”S, 4355'12”W, 03.VII.2017, fr., K.F. Silva 231 (UB); Sítio Novo, 0556'24”S, 46³7'12”W, 20.VII.2017, fr., R.M.G. Konopczyk 352 (UB); Viana, 1-2 km S of entrance of the city, $03^{\circ} 13^{\prime} \mathrm{S}, 45^{\circ} 00^{\prime} \mathrm{W}$, 30.VIII.1994, fr., L.R. Noblick \& I.G. Souza 4967 (MAR, NY).
11. Bactris acanthocarpa var. exscapa Barb.Rodr., Enum. Palm. Nov.: 31. 1875. Figure 6a-b.

Solitary or clustered, acaulescent or caulescent palm with up to 3 $\mathrm{m}$ tall that is differentiated by its numerous rachillae, 20-49 in number, filiform ( $<1 \mathrm{~mm}$ in diameter), unarmed, as well as by its globose fruits, $1.2-2 \mathrm{~cm}$ in diameter, armed, and reddish when ripe.

Common names: marajá, kwere'i (Ka'apor), pupunha-mansawa'ã (Guajá), dendê-de-urubu, marajá-piranga, mumbaca, pupuinha, pupunha, pupunha-de-mata, tucum, and tucumã.

Distribution and ecology: This species is widespread in Bolivia, Peru, Ecuador, Colombia, Venezuela, Guyana and Brazil (Acre, Amazonas, Maranhão, Pará, and Rondônia), inhabiting terra firme forests of the Amazon domain (Henderson 2000, Flora do Brasil 2020 under construction). In Maranhão, it was found in fragments of the Amazonian forest in the northwest region (Figure 2d), with flowers in November and fruits from November to June.

Conservation: Bactris acanthocarpa var. exscapa is assessed as Endangered [EN B1ab (iii)] for Maranhão since it has an EOO of 597.739 $\mathrm{km}^{2}$ and there are only five records for the species in different locations. Moreover, this palm exhibits a severe loss of the habitat extent, because it is associated with environments of primary forests that are currently restricted to small areas of the Maranhão territory (Celentano et al. 2017).

Material examined: BRAZIL, MARANHÃO: Cândido Mendes, fragmento de floresta amazônica da Fazenda Sete Irmãos, 01 ${ }^{\circ} 51$ '13"S, 4546'13.2”W, 04.XI.2017, fl., G.P. Lima et al. 675 (MAR); Governador Nunes Freire, km 6 da BR 106 (Maracaçumé - Santa Helena), Fazenda Maracaçumé Agro Industrial Grupo Mesbla, 02.XII.1978, fr., N.A. Rosa \& B. Vilar 2826 (MG); P.I. Guajá (Terra Indígena Alto Turiaçu), rio Turiaçu, Guajá Indians, 0307’'S, 4605'W, 17.VI.1987, fr., W. Balée 3355 (MG, NY); Basin of the rio Turiaçu, Ka'apor Indian Reserve (T.I. Alto Turiaçu), 4 km NW of settlement of Urutawy, 12.II.1985, fr., W.L. Balée \& B.G. Ribeiro 679 (MG, NY); Urutawi, Ka'apor Indian Reserve (T.I. Alto Turiaçu), basin of rio Turiaçu, 4.VII.1987, st., W. Balée 3546 (NY).

12. Bactris brongniartii Mart., Voy. Amér. Mér. 7(3): 59-60. 1846. Figure 6c-f.

Bactris brongniartii is a clustered and caulescent palm with up to 6 $\mathrm{m}$ tall that resembles Bactris campestris due to its numerous rachillae with a diameter greater than $1 \mathrm{~mm}$ and its unarmed fruits. However, it can be differentiated by its yellowish flattened spines, found in sheath, petiole, and rachis, as well as by the depressed-globose fruits, $1-1.6 \mathrm{~cm}$ in diameter, black-purplish when mature, and with staminodial ring in the persistent perianth.

Common names: marajá, marajá-do-campo, maraja'y (Ka'apor), maria-ci and maria-wa (Guajá), marajá-de-cacho, marajá pupunha, and tucum-bravo.

Distribution and ecology: $B$. brongniartii is frequent in most of the Amazon biome, being present in Bolivia, Peru, Colombia, Venezuela, Guyana, and Brazil (Acre, Amazonas, Maranhão, Mato Grosso, Mato Grosso do Sul, Pará, Rondônia, and Roraima). It prefers river banks, seasonally flooded areas, and also primary and secondary terra firme forests (Henderson 2000, Pinheiro 2011, Flora do Brasil 2020 under construction). In Maranhão, it was found in the indigenous lands of the Amazon forest and the margins of the Baixada Maranhense rivers and lakes (Figure 2d), with flowers in August and fruits from June to September. 
Synopsis of the tribe Cocoseae Mart. in Maranhão

a
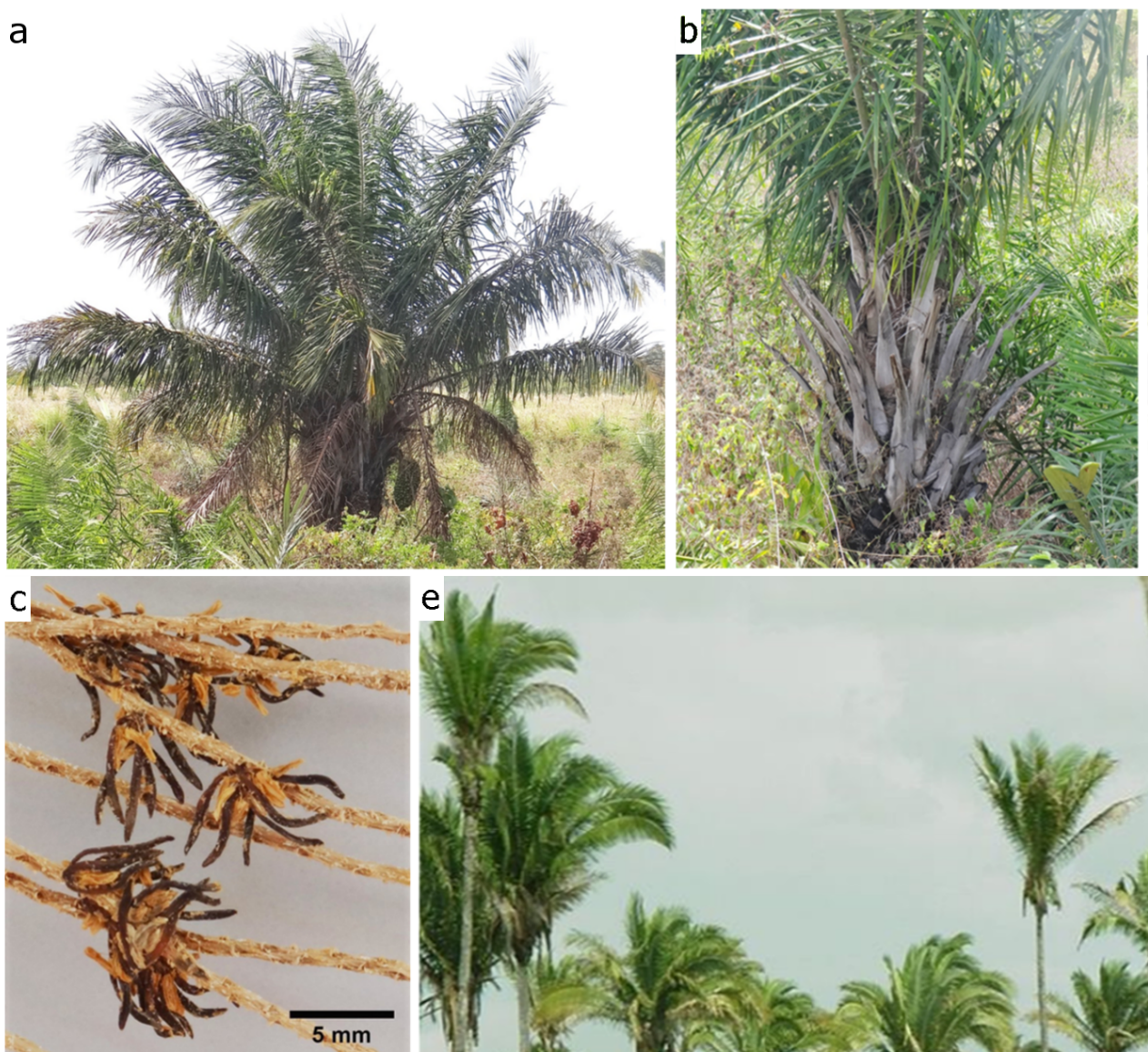
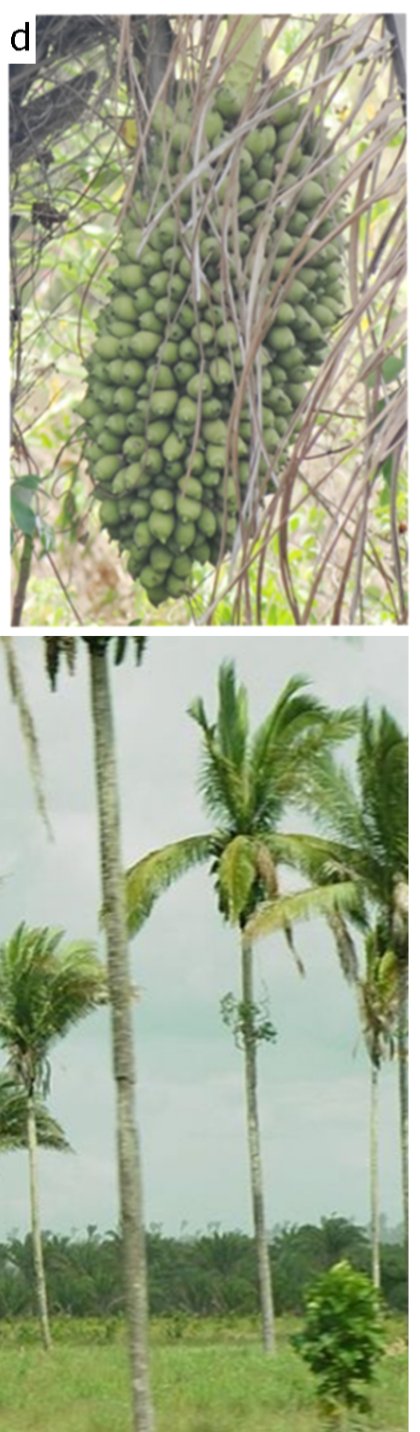

$f$

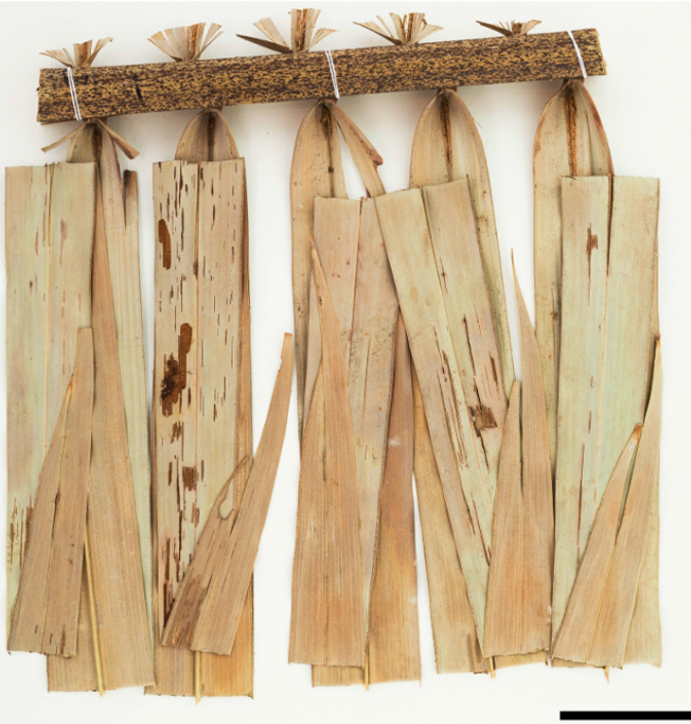

$5 \mathrm{~cm}$

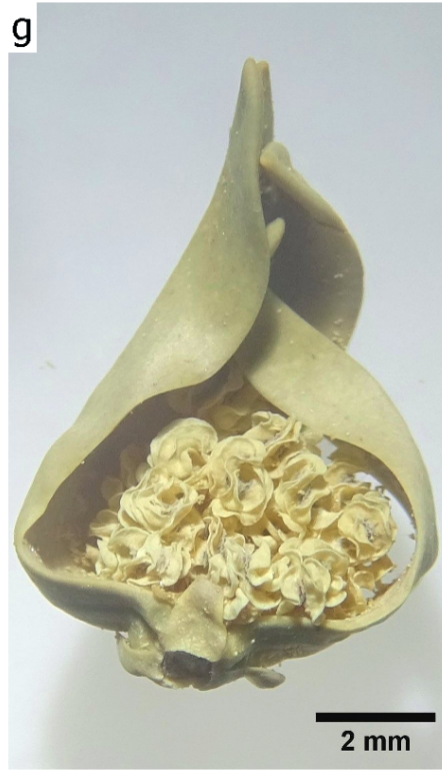

Figure 5. a-d. Attalea phalerata; a. palm in its natural environment (G.P. Lima et al. 680); b. stem covered with remnants leaf sheaths (G.P. Lima et al. 680); c. staminate flowers with brownish linear petals and yellowish straight anthers shorter than the petals (E.L. Perez et al. 2067); d. infructescence (G.P. Lima et al. 680). e-h. Attalea speciosa; e. palms in their the natural environment; f. middle pinnae distributed regularly and arranged in the same plane along the rachis (L.R. Noblick et al. 4967); g. staminate flower with spirally twisted and coiled anthers (M.J. Balick et al. 1528); h. infructescence. 


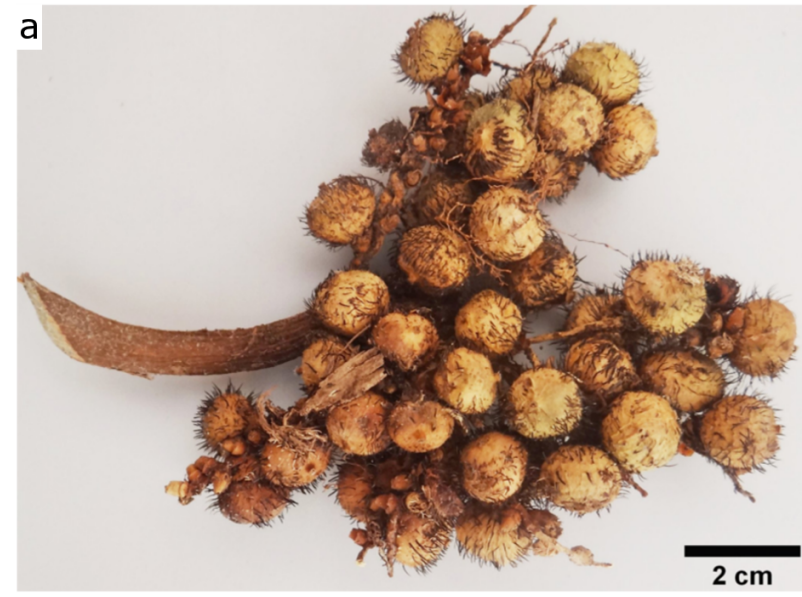

d
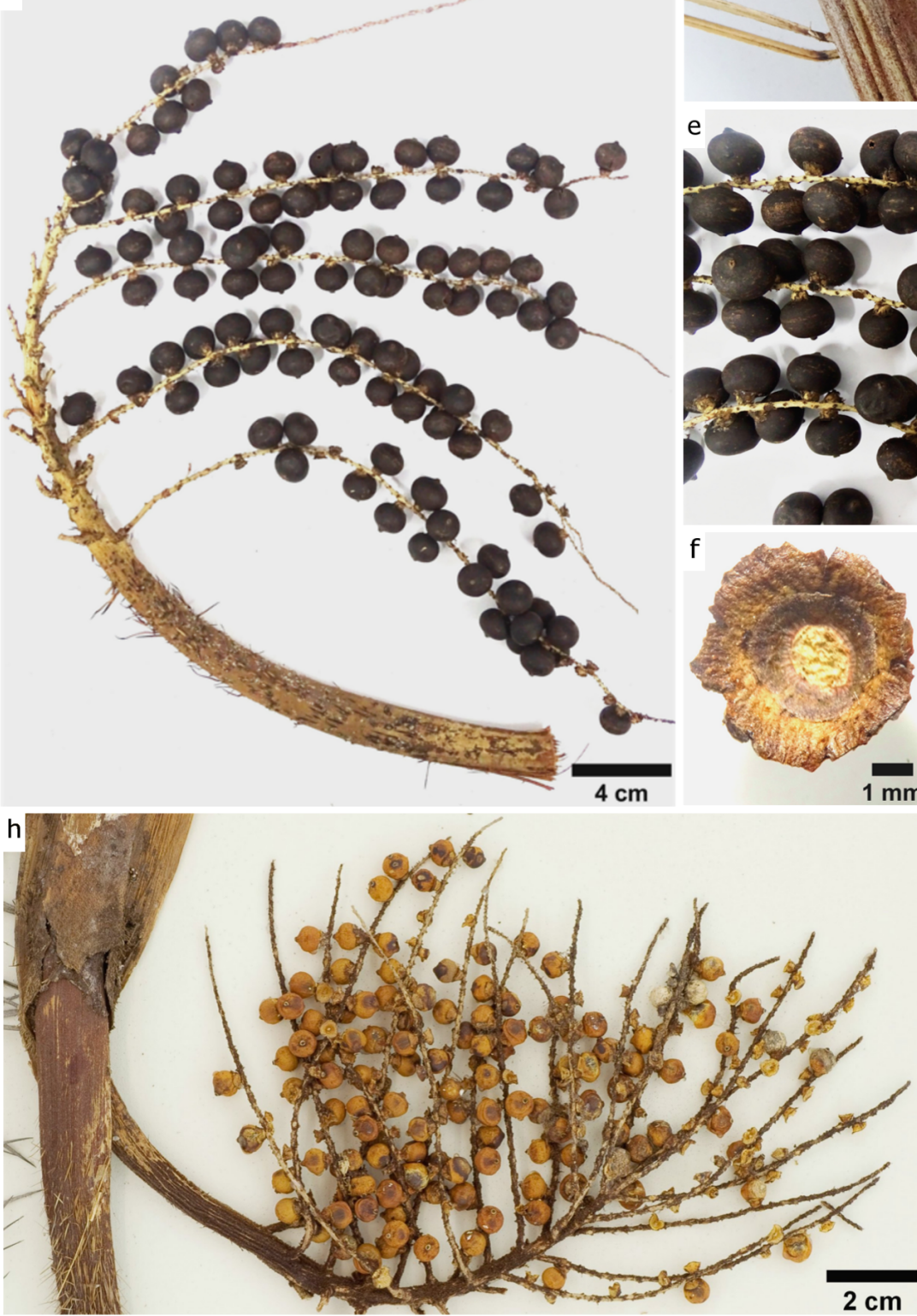
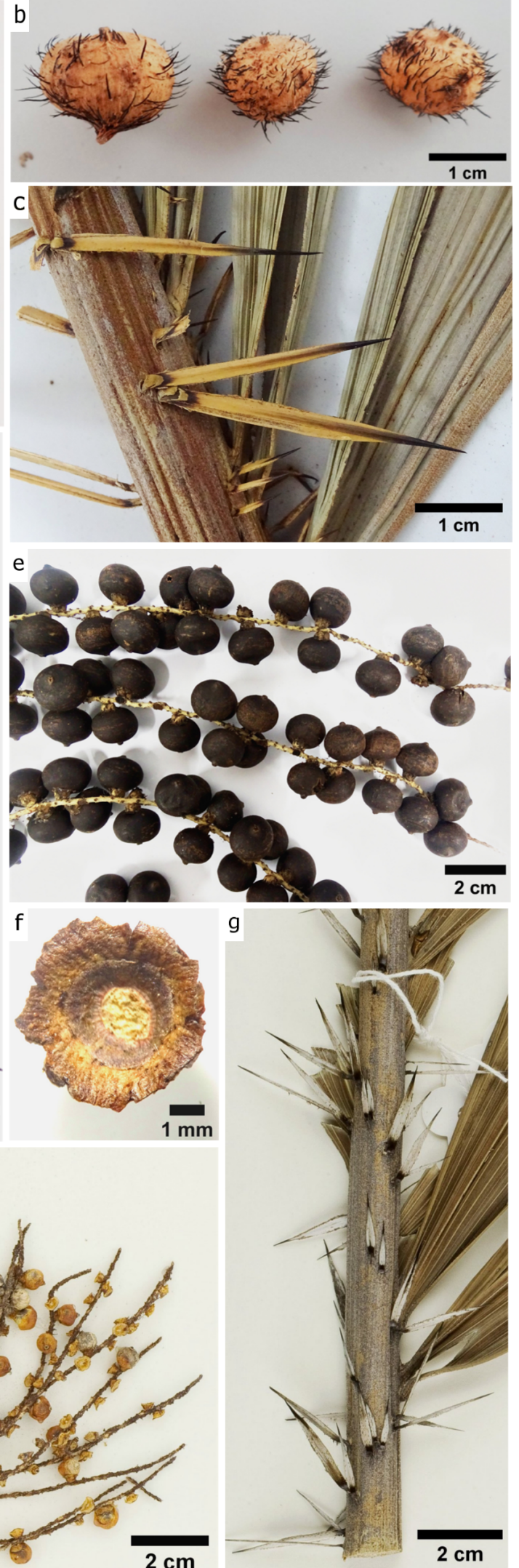

Figure 6. a-b. Bactris acanthocarpa var. exscapa; a. inflorescence with filiform rachillae (A.J. Henderson et al. 1159); b. armed fruits (A.J. Henderson et al. 1159). c-f. Bactris brongniartii; c. yellowish flattened spines (L.R. Noblick \& I.G. Souza 4968); d. inflorescence with fruits (L.R. Noblick \& I.G. Souza 4968); e. mature fruits (L.R. Noblick \& I.G. Souza 4968); f. staminodial ring in the persistent perianth of the fruit (L.R. Noblick \& I.G. Souza 4968). g-h. Bactris campestris; g. grayish-brown flattened spines (S.A. Mori \& R. Cardoso 17287); h. orangish mature fruits and reddish-brown indument in the inflorescence. (S.A. Mori et al. 25319). 
Conservation: According to IUCN (2012) criteria, this species is considered as Vulnerable [VU B1ab(iii)] since it has an EOO of $10,742.057 \mathrm{~km}^{2}$ and it is known in only seven different locations in Maranhão. Aside from that, there is a marked decline in the extent of primary forests in the north and northwest regions of the State, which are one of the preferential habitats of the species (Celentano et al. 2017).

Material examined: BRAZIL, MARANHÃO: Cândido Mendes, fragmento de floresta amazônica da Fazenda Sete Irmãos, 01 '51'13"S 45 46'13.2”W, 03.XI.2017, st., G.P. Lima et al. 665 (MAR); Viana, 2 $\mathrm{km} \mathrm{S}$ of entrance to the city, margins of the rio Macatu, 30.VIII.1994, $03^{\circ} 13^{\prime}$ S, 4500'W, fl. and fr., L.R. Noblick 4968 (IPA, MAR, NY); Basin of the rio Turiaçu, Ka'apor Indian Reserve (T.I. Alto Turiaçu), 7 km NW of settlement of Urutawy, 15.II.1985, fr., W.L. Balée \& B.G. Ribeiro 824 (MG, NY); Bom Jardim, Posto Indígena Pindaré (FUNAI Post - Guajajara Indians), along rio Pindaré, ca. $15 \mathrm{~km} \mathrm{~W}$ of Santa Inês, 03³0’S, 45³0’W, 1.IX.1983, st., M.J. Balick et al. 1525 (CEN, NY); P.I Guajá (T.I. Alto Turiaçu), rio Turiaçu, Guajá Indians, $03^{\circ} 07^{\prime} \mathrm{S}, 46^{\circ} 05^{\prime} \mathrm{W}$, 18.VI.1987, fr., W. Balée 3385 (MG, NY); Lago Verde, Fazenda São Francisco, estrada Alto Alegre - Lago Verde, km 9, 24.III.1985, st., A.B. Anderson et al. 2180 (MG); Vitória do Mearim, 26.XI.1978, st., N.A. Rosa \& O. Cardoso 2597 (MG).

13. Bactris campestris Poepp. ex Mart., Hist. Nat. Palm. 2: 146. 1837. Figure 6g-h.

Clustered and caulescent palm with 1.8-2.6 m tall that can be confused with Bactris brongniartii, as mentioned previously. However, Bactris campestris differs from that taxon by the following characteristics: grayish or brownish flattened spines found in sheath, petiole, and rachis, and by the presence of dense reddish-brown indument in the inflorescence, as well as by the depressed-globose fruits with $0.5-0.8 \mathrm{~cm}$ in diameter, reddish-orange when mature.

Common names: marajá and mumbaca-branca.

Distribution and ecology: This palm is widely distributed in northeastern South America, occurring in Colombia, Venezuela, Trinidad and Tobago, Guianas, and Brazil (Amapá, Amazonas, Maranhão, Pará, and Roraima). It grows in open areas, savannas or low forests on white sand (campinaranas), generally in poorly drained places (Henderson 2000, Flora do Brasil 2020 under construction). In Maranhão, the only specimen observed to date was collected in the 1950s in a flooded field area in the low course of the Gurupi River, with fruits in March (Figure 2d).

Conservation: $B$. campestris is classified as Data Deficient (DD) for the territory of Maranhão since it has only a single occurrence record, which was collected 60 years ago. New researches are urgently necessary so that its conservation status can be adequately documented, considering the high degradation level of the Amazon in the State (Celentano et al. 2017).

Material examined: BRAZIL, MARANHÃO: Rio Gurupi, 19.III.1958, fr., R.L. Fróes 34235 (IAN).

14. Bactris hirta var. pectinata (Mart.) Govaerts, World Checkl. Palms: 26. 2005. Figure 7a-c.

Bactris hirta Mart. is one of the most variable species in the genus, especially concerning the division, shape, and the size of the leaf. There are several distinct local forms, and some of these are recognized as varieties (Henderson 2000). Currently, three varieties are reported in Brazil (Flora do Brasil 2020 under construction), but only Bactris hirta var. pectinata was cataloged in the present study. This variety is a solitary or clustered, caulescent palm with $0.7-2.5 \mathrm{~m}$ tall that can be identified by its branched inflorescence up to first order with 2-4 rachillae, and globular armed fruits, less than $1 \mathrm{~cm}$ in diameter, reddish when ripe.

Common names: marajá, marajazinho, aricanga-falsa, tucummirim, and ubimrana.

Distribution and ecology: It is distributed in Bolivia, Peru, Colombia, Venezuela, Guianas and Brazil (Amapá, Amazonas, Bahia, Espírito Santo, Maranhão, Pará, Pernambuco, and Rondônia), and typically found in terra firme forests (Henderson 2000, Flora do Brasil 2020 under construction). In Maranhão, this taxon was collected in Amazonian forest fragments in the northwest region (Figure 2d), with flowers in June and November, and fruits in November.

Conservation: $B$. hirta var. pectinata has an EOO of 5,316.095 km² and is known in only three different locations in Maranhão. Moreover, the habitat of this species in the Maranhão Amazon shows a marked decline in its extension and also in its quality, especially outside the conservation units (Celentano et al. 2017). For these reasons, this taxon is categorized in the present study as Vulnerable [VU B1ab(iii)] according to IUCN (2012) criteria.

Material examined: BRAZIL, MARANHÃO: Cândido Mendes, fragmento de floresta amazônica da Fazenda Sete Irmãos, $01^{\circ} 51$ '13'S, 45 46'13.2”W, 03-04.XI.2017, fr., G.P. Lima et al. 663 (MAR) and 672 (MAR); Nova Olinda, P.I. Guajá (T.I. Alto Turiaçu), rio Turiaçu, 0307'S, 46º5'W, 29.VI.1987, fl., W. Balée 3499 (NY); Pinheiro, povoado Purão dos Pirróis, ramal Família Viveira, $02^{\circ} 40,45^{\prime} \mathrm{S}$, $45^{\circ} 15,17^{\prime}$ W, 24.IX.2017, fl. and fr., A.W.C. Ferreira s.n. (MAR).

15. Bactris major var. infesta (Mart.) Drude, Fl. Bras. 3(2): 359. 1881. Figure 7d-e.

Bactris major var. infesta is a clustered or rarely solitary, caulescent palm with 2-4 $\mathrm{m}$ tall. This species is differentiated by its branched inflorescence up to first order with 2-3 rachillae and by its obovoid or ellipsoid fruits with $2.6-4 \mathrm{~cm}$ long (vs. fruits $<2.2 \mathrm{~cm}$ long, in the other species of Bactris).

Common names: marajá, piri'a-hu (Ka'apor), and tucum-mirim.

Distribution and ecology: B. major var. infesta occurs in Bolivia, Peru, Ecuador, Venezuela, Guyana, and Brazil (Acre, Amazonas, Maranhão, Pará, Rondônia, and Tocantins). It is found in terra firme forests, secondary forests or open pasture areas (Lorenzi et al. 2010). In Maranhão, this palm is reported in pastureland or terra firme forests in Maracaçumé and Turiaçu drainage basins, and also in some locations surrounding Tocantins River, near the towns of Carolina and Imperatriz (Figure 8a). The specimens were obtained with flowers in January and fruits in January, May, July, and November.

Conservation: Based on the $\operatorname{EOO}\left(3,609.302 \mathrm{~km}^{2}\right)$ and on the few locations where it is known, B. major var. infesta could be assessed as Endangered (EN) for Maranhão. However, according to Henderson (2000), this species can be found in secondary environments, colonizing disturbed areas subject to temporary flooding, which was observed in studies carried out in the town of Cândido Mendes. Having said that and following IUCN (2012) criteria, we propose that the status of Near Threatened (NT) is the most realistic assessment for B. major var. infesta in the state of Maranhão. 

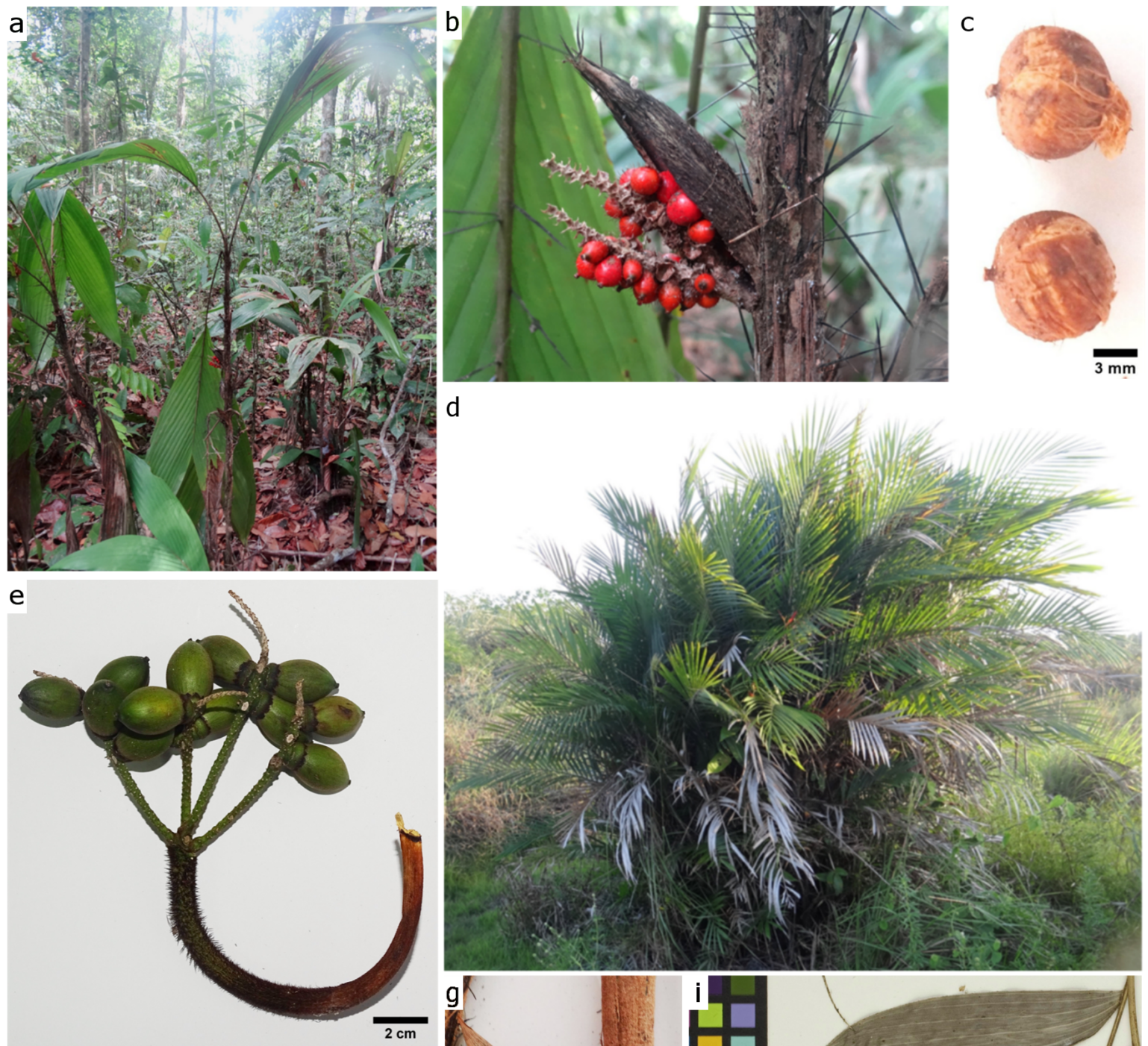

d
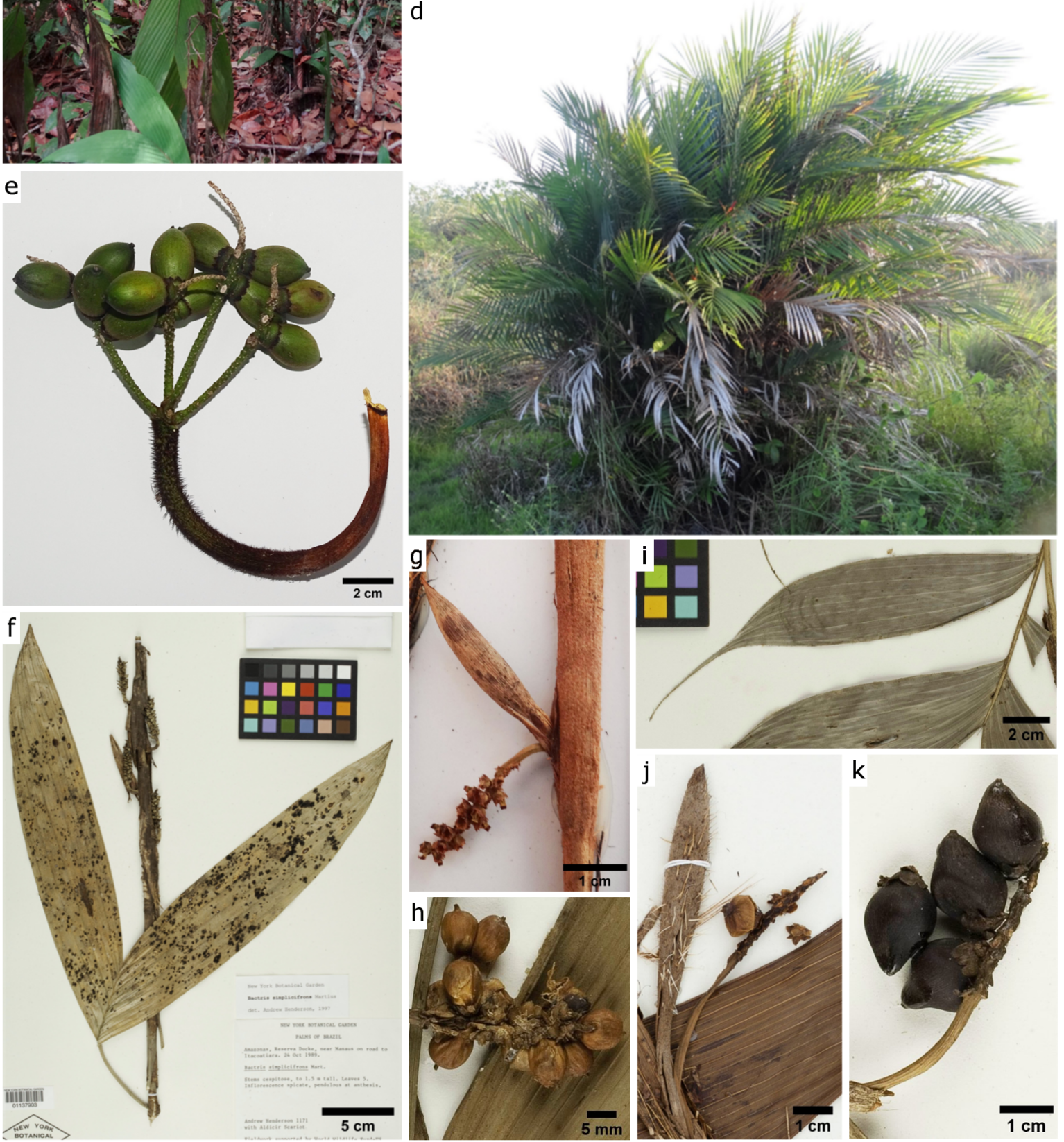

Figure 7. a-c. Bactris hirta var. pectinata; a. palm in its natural environment (G.P. Lima et al. 672); b. inflorescence with mature fruits (G.P. Lima et al. 672); c. fruits (A.J. Henderson et al. 883); d-e. Bactris major var. infesta; d. clustered palm in its natural environment; e. inflorescence with fruits (G.P. Lima et al. 677). f-h. Bactris simplicifrons; f. leaf blade (A.J. Henderson et al. 1171); g. unarmed peduncular bract and inflorescence axis pending (A.O. Scariot 618); h. fruits (J.E.L.S. Ribeiro et al. 1242). i-k. Bactris tomentosa; i. pinna with filiform apex (A.J. Henderson et al. 1060); j. armed peduncular bract and unbranched inflorescence (W.L. Balée 3495); k. mature fruits (A.J. Henderson et al. 1501). 

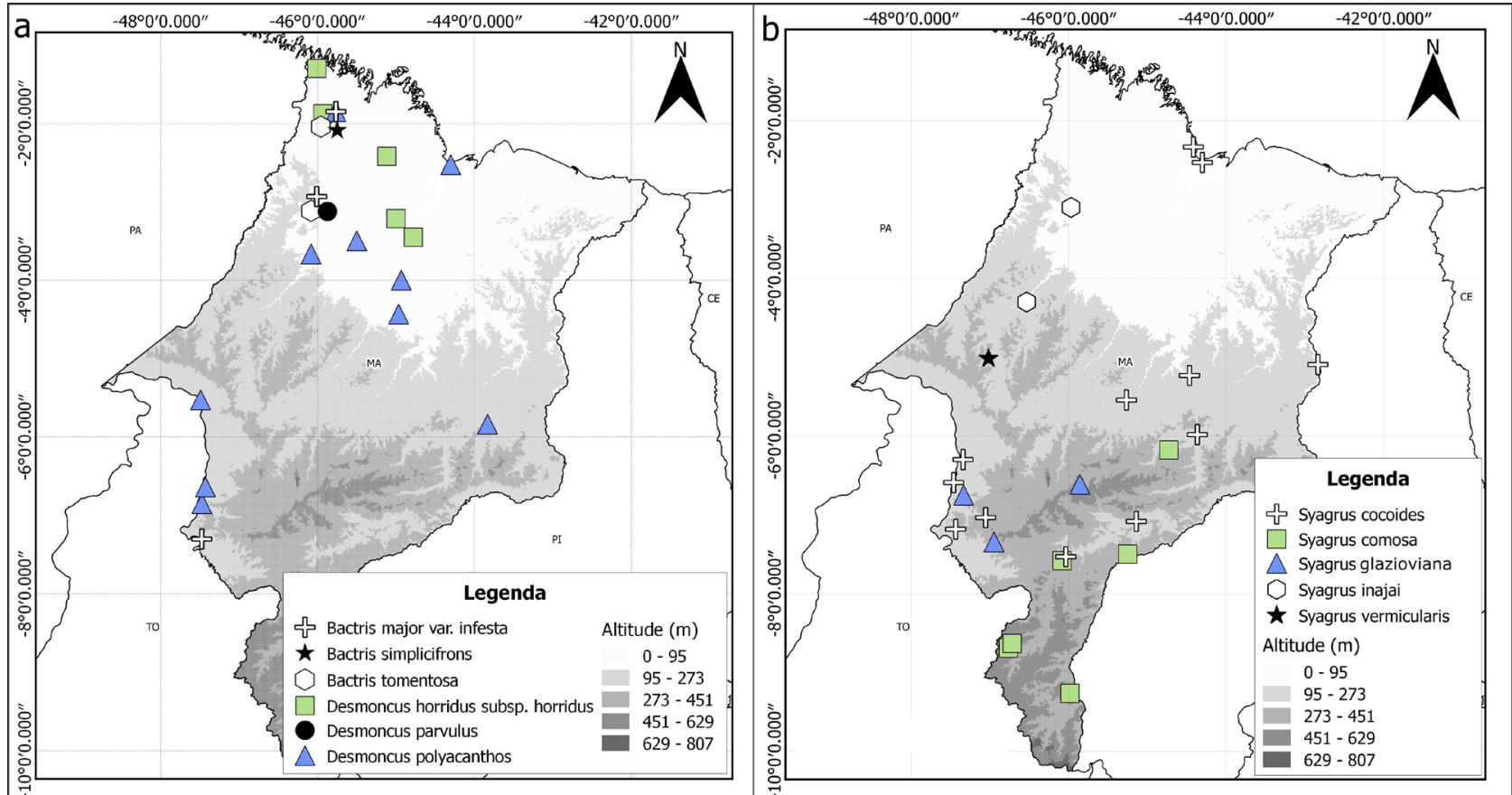

Figure 8. a. Distribution maps of Bactris major var. infesta, Bactris simplicifrons, Bactris tomentosa, Desmoncus horridus subsp. horridus, Desmoncus parvulus, and Desmoncus polyacanthos. b. Distribution maps of Syagrus cocoides, Syagrus comosa, Syagrus glazioviana, Syagrus inajai, and Syagrus vermicularis. Source: prepared by the authors.

Material examined: BRAZIL, MARANHÃO: Cândido Mendes, campo próximo da sede da Fazenda Sete Irmãos, 0151'30.9'S, 4548'13.7'W, 04.XI.2017, fr., G.P. Lima et al. 677 (MAR); Carolina, duas léguas abaixo de Carolina, rio Tocantins, 29.V.1950, fr., J.M. Pires \& G.A. Black 2474 (IAN); Carolina, estrada de acesso ao porto de Babaçulândia, margem direita do rio Tocantins, 07²18'04'S, 47²8'37'W, 16.I.2008, fl. and fr., G. Pereira-Silva et al. 12707 (CEN); Urutawi, Ka'apor Indian Reserve (T.I. Alto Turiaçu), basin of rio Turiaçu, 04.VII.1987, fr., W. Balée 3545 (NY).

16. Bactris simplicifrons Mart., Hist. Nat. Palm. 2: 103. 1826. Figure $7 f-h$.

Solitary or clustered, caulescent palm with $0.5-1.5 \mathrm{~m}$ tall that is recognized by the absence of spines on almost all structures, there are just small spines $(\leq 3 \mathrm{~mm}$ ) on apex margins of the leaf blades and rarely on sheaths and petioles. Other notable characteristics are leaf blades usually sigmoid, shaped like a whale's tail, as reported by Henderson (2000), the inflorescence axes pending, unarmed, peduncular bracts erect and near the stem at anthesis and forming an angle of $45^{\circ}$ with respect to the stem, after the fruiting.

Common names: marajá, ubim-mirim, and ubimzinho.

Distribution and ecology: This species has a broad distribution in the Amazon region, occurring in Bolivia, Ecuador, Peru, Colombia, Venezuela, Trinidad and Tobago, Guianas, and Brazil (Acre, Amazonas, Amapá, Maranhão, Pará, Rondônia, and Roraima) (Henderson 2000, Flora do Brasil 2020 under construction). It grows in primary and secondary forests of terra firme or campinaranas (Lorenzi et al. 2010). In the state of Maranhão, there is only one record for Bactris simplicifrons. This specimen was collected in an Amazonian forest fragment of the northwest region of the State (Figure 8a), with fruits in November.
Conservation: More information is needed to evaluate the conservation status of $B$. simplicifrons, given that there are records of this species in only one place in Maranhão. For this reason and following IUCN (2012) criteria, this palm is preliminarily assessed as Data Deficient (DD).

Material examined: BRAZIL, MARANHÃO: Governador Nunes Freire, km 6 da MA 106 (Maracaçumé - Santa Helena), Fazenda Maracaçumé Agro Industrial Grupo Mesbla, 30.XI.1978, fr., N.A. Rosa \& B. Villar 2773 (MG, NY).

17. Bactris tomentosa Mart., Hist. Nat. Palm. 2: 100. 1826. Figure $7 \mathrm{i}-\mathrm{k}$.

Clustered and caulescent palm with $1.5-3 \mathrm{~m}$ tall that can be distinguished by its sigmoid or elliptic-lanceolate pinnae with filiform apex, unbranched inflorescences, and obovoid fruits, 1.9-2.2 cm long, black-purplish when mature.

Common names: marajá and marajazinho.

Distribution and ecology: It occurs in primary forests of terra firme in Brazil (Acre, Amazonas, Pará, Amapá, and Maranhão), French Guiana, and Suriname (Henderson 2000, Lorenzi et al. 2010, Flora do Brasil 2020 under construction). In Maranhão, the samples were collected at the Alto Turiaçu Indigenous Land and in the town of Maracaçumé, areas under Amazonian influence in the northwest region of the State (Figure 8a). It was found with flowers in July and September, and with fruits from June to August.

Conservation: Bactris tomentosa is classified as Endangered [EN $\mathrm{B} 1 \mathrm{ab}$ (iii)] for Maranhão since it has an $\mathrm{EOO}$ of $338.551 \mathrm{~km}^{2}$ and has less than five records in different locations. Moreover, it is possible to observe a marked decline in the extent and quality in this species habitat, considering that currently there is only $25 \%$ of the original Amazonian vegetation in the State (Celentano et al. 2017). 
Material examined: BRAZIL, MARANHÃO: Basin of the rio Turiaçu, Ka'apor Indian Reserve, within $7 \mathrm{~km}$ of the settlement of Urutawy, 09.VI.1985, fr., W. Balée 1014 (MG); km 428 da Rodovia Belém-Brasília, 08.IX.1960, fr., E. Oliveira 1131 (IAN); Maracaçumé, 07.VII.1958, fr., R.L. Froés 34449 (IAN); Nova Olinda, P.I. Guajá (T.I. Alto Turiaçu), rio Turiaçu, $03^{\circ} 07^{\prime}$ 'S, $46^{\circ} 05^{\prime} \mathrm{W}, 28$. VI.1987, fr., W. Balée 3495 (MG, NY); Nova Olinda, P.I. Guajá (T.I. Alto Turiaçu), rio Turiaçu, 0307'S, 4605'W, 30.VI.1987, fr., W. Balée 3525 (MG, NY).

18. Desmoncus horridus Splitg. ex Martius subsp. horridus, Voy. Amér. Mér. 7(3): 51. 1844. Figure 9a-b.

Clustered, caulescent and climbing palm with 2-15 m tall that can be identified by its spines of the petiole and rachis greater than $1 \mathrm{~cm}$ long, straight and without markedly swollen bases.

Common name: jacitara.

Distribution and ecology: It occurs in Trinidad and Tobago, Venezuela, Guianas and Brazil (Maranhão, Pará, and Tocantins), mostly in open places of coastal zones, often along river margins (Henderson 2011, Flora do Brasil 2020 under construction). In Maranhão, it was recorded in margins of rivers and flood plains located in the Baixada Maranhense, and also in the western coast, near the border with the state of Pará (Figure 8a). Through the examined material, it was observed fruiting in May, August, and November.

Conservation: Desmoncus horridus subsp. horridus is classified as Vulnerable [VU B1ab(iii)] for Maranhão since it has an EOO of $8,288.641 \mathrm{~km}^{2}$ and has only five different records. Machado \& Pinheiro (2016) mentioned signs of anthropic pressure on riparian vegetation in Baixada Maranhense, where this species occurs. The authors point out that the environmental changes caused by humans have been gradually modifying the vegetation, making it less diverse and dominated by more tolerant species.

Material examined: BRAZIL, MARANHÃO: Arari, Povoado Engenho, 30.VI.1978, st., N.A. Rosa 2470 (MG); Carutapera, margem do rio Gurupi, $01^{\circ} 18^{\prime} 00$ 'S, 4600'36”W, 27.V.2010, fr., E.S. Leal et al. 140 (MG, RB); Pinheiro, em direção a Central do Maranhão na MA006, 02²5'16.8”S, 4506'59.6”W, 05.XI.2017, st., G.P. Lima et al. 682 (MAR); Rio Maracaçumé, 25.XI.1932, fr., R. Fróes 2001 (NY); Viana, ca. $2 \mathrm{~km} \mathrm{~S}$ of entrance to the city, margins of the rio Macatu, $03^{\circ} 13^{\prime} \mathrm{S}$, 4500'W, 30.VIII.1994, fr., L.R. Noblick et al. 4968 (IPA, MAR).

19. Desmoncus parvulus L.H.Bailey, Bull. Torrey Bot. Club 75: 115. 1948. Figure 9g.

Desmoncus parvulus is a clustered, caulescent and climbing palm with 1.8-4 m tall. It differs from Desmoncus horridus subsp. horridus by the presence of spines on the petiole and rachis less than $1 \mathrm{~cm}$ long, recurved and with markedly swollen bases, which are morphological characteristics also present in Desmoncus polyacanthos. On the other hand, it diverges from $D$. polyacanthos by its spines arranged along the cirrus. Desmoncus polyacanthos has spines only on the proximal and abaxial part of the cirrus.

Common names: jacitara, iraparpukwaba (Ka'apor), and pijacicara.

Distribution and ecology: This palm occurs in Amapá, Amazonas, Maranhão, and Pará states, generally growing in lowland rainforests (Henderson 2011, Flora do Brasil 2020 under construction). Also, it is widespread in Colombia, Venezuela, and Guyana (Henderson 2011). In Maranhão, there is only one record for this species at Alto Turiaçu
Indigenous Land, which is the largest remaining fragment of the Amazon forest in the State (Figure 8a), with fruits in May.

Conservation: D. parvulus is assessed as Data Deficient (DD) for Maranhão since it has only one record of occurrence, which was more than 30 years ago. The lack of robust data makes it difficult to infer its conservation status. For this reason, further surveys are needed to elucidate the distributional range of this species in the State.

Material examined: BRAZIL, MARANHÃO: Ka'apor Indian Reserve (T.I. Alto Turiaçu), 10.V.1986, fr., W.L. Balée 2301 (NY).

20. Desmoncus polyacanthos Mart., Hist. Nat. Palm. 2(3): 85-86. 1824. Figure 9c-f.

Desmoncus polyacanthos is a clustered, caulescent and climbing palm with $1.5-8 \mathrm{~m}$ tall. It is the second most variable species in the genus, possibly due to its wide geographic distribution (Henderson 2011). Despite intraspecific differences between populations, $D$. polyacanthos can be distinguished from the other species of Desmoncus by the shape, size and arrangement of spines, as described in the previous comments.

Common names: titara, espera-i, and jacitara.

Distribution and ecology: This species occurs in Bolivia, Peru, Ecuador, Colombia, Venezuela, Trinidad and Tobago, Guianas, and Brazil (Henderson 2011). In Brazil, D. polyacanthos has a disjoint distribution between the Amazon and Atlantic Forest, occurring in the states of Acre, Alagoas, Amazonas, Amapá, Bahia, Espírito Santo, Goiás, Maranhão, Mato Grosso, Minas Gerais, Pará, Paraíba, Pernambuco, Rio de Janeiro, Rio Grande do Norte, and Roraima (Flora do Brasil 2020 under construction). The populations grow in a wide variety of habitats, such as terra firme forests, flooded forests, campinas, and restingas (Henderson 2011). In Maranhão, it was found in the north, west, southwest and east regions, in areas of secondary vegetation or riparian forests (Figure 8a), with flowers from January to October and fruits from February to March.

Conservation: It is assessed as Least Concern (LC) for Maranhão, with an EOO of 144,029.058 $\mathrm{km}^{2}$.

Material examined: BRAZIL, MARANHÃO: Bom Jardim, Posto Indígena Carú (FUNAI Post - Guajajara Indians), along rio Pindaré near junction of rio Carú, 030 $40^{\prime} \mathrm{S}, 46^{\circ} 05^{\prime} \mathrm{W}, 28$.VII.1983, st., M.J. Balick et al. 1470 (MG); Bom Jardim, Posto Indígena Pindaré (FUNAI Post - Guajajara Indians), along rio Pindaré, ca. $15 \mathrm{~km} \mathrm{~W}$ of Santa Inês, 0330'S, 45³0'W, 01.IX.1983, fl., M.J. Balick et al. 1493 (SP); Buriti Bravo, margem direita do rio Itapecuru, Serra dos Papaguaios, 23.II.1983, fr., N.A. Rosa et al. 665 (MG); Cândido Mendes, campo próximo da sede da Fazenda Sete Irmãos, 01 ${ }^{\circ} 51^{\prime} 30.9^{\prime}$ 'S, 4548'13.7'W, 04.XI.2017, st., G.P. Lima et al. 661 (MAR); Estreito, margem direita do rio Farinha, 06 51 '01'’S, 47²8'31'W, 25.IV.2008, fl., G. Pereira-Silva et al. 13316 (CEN); Estreito, Barra Vereda, Fazenda Balneário das Pedras, margem esquerda do rio, $06^{\circ} 38^{\prime} 13^{\prime \prime}$, $47^{\circ} 25^{\prime} 48^{\prime \prime} \mathrm{W}, 22 . I I .2005$, fr., G. Pereira-Silva et al. 9567 (CEN); Ilha do Maranhão, II-III.1939, fl., R. Fróes 11765 (NY); Imperatriz, behind Rodobrás station on south side of city of Imperatriz, 06.I.1970, fl., G. Eiten \& L.T. Eiten 10208 (SP); Lago do Junco, Fazenda Bacaba, $5 \mathrm{~km} \mathrm{~S}$ of MA-119 from entrance

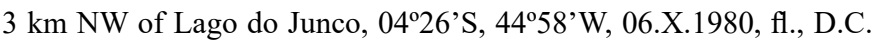
Daly et al. 535 (MG, NY); Lago Verde, Fazenda São Francisco, estrada Alto Alegre - Lago Verde, 21.III.1985, fr., A.B. Anderson et al. 2041 
Synopsis of the tribe Cocoseae Mart. in Maranhão
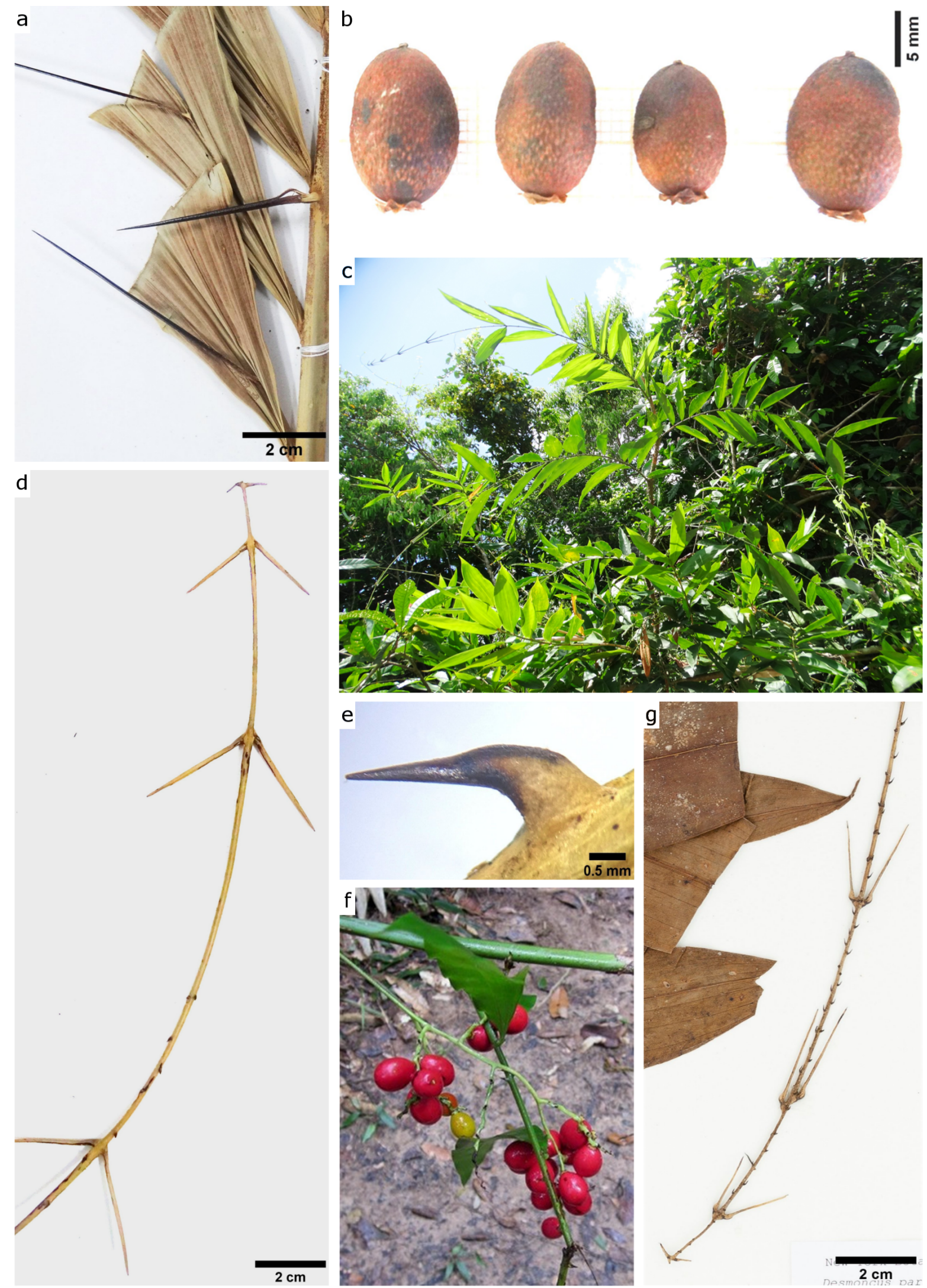

Figure 9. a-b. Desmoncus horridus subsp. horridus; a. spines of the pinnae and the rachis (L.R. Noblick et al. 4968); b. fruits (E.S. Leal et al. 140). c-f. Desmoncus polyacanthos; c. palm in its natural environment; d. the distal part of the cirrus without spines (R. Barros et al. 1059); e. spine of the rachis (R. Barros et al. 1059); f. mature fruits (A.M. Miranda 6736). g. Desmoncus parvulus - spines on the distal part of the cirrus (R.C. Ek et al. 835). 
(MG); Nova Olinda, P.I. Guajá (T.I. Alto Turiaçu), rio Turiaçu, $03^{\circ} 07^{\prime}$ S, 4605’W, 29.VI.1987, st., W. Balée 3500 (NY).

21. Syagrus cocoides Mart., Hist. Nat. Palm. 2: 130. 1826. Figure 10a-b.

Solitary and caulescent palm with 1-9 m tall that is distinguished from the others by its piriform fruits (pear-shaped). In the vegetative state, it can be confused with Syagrus inajai. However, Syagrus cocoides differs by its striate stem (vs. smooth stem in S. inajai) and by the absence of prominent cross-veins on the abaxial surface of the pinnae (vs. presence of prominent cross-veins in S. inajai).

Common names: ariri, pati, iriri, jatá, jatá-uva, and piririma.

Distribution and ecology: $S$. cocoides occurs in the states of Amazonas, Goiás, Maranhão, Mato Grosso, Pará, Piauí, and Tocantins. Generally, it grows in the Amazonian or Pre-Amazonian forest (terra firme forest) and gallery forest, but it can also be found in the Cerrado biome in rocky terrains up to $500 \mathrm{~m}$ altitude (Noblick 2017). In Maranhão, it is one of the most collected palms, with records mainly in the north, central, and southern regions (Figure 8b). The specimens were collected with flowers from December to May and fruits between March and December. According to Noblick (2017), the flowering occurs around December and the fruiting in August and September.

Conservation: This species is assessed as Least Concern (LC) for Maranhão since it has an EOO of 145,939.992 km². Noblick (2017) also classified this species as LC, because according to this author, it is widely distributed throughout Brazil and there are not severe threats to its habitat.

Material examined: BRAZIL, MARANHÃO: Alcântara, sub-bacia dos rios Pepital e Grande, 02²0'00'S, 4425'00”W, 11.XI.2012, fr., E.C.M. Oliveira s.n. (MAR); Balsas, ca. $25 \mathrm{~km} \mathrm{~W}$ of Balsas, Farm of Sr. Damion, 03-04.XII.1981, fl., M.J. Balick et al. 1343 (CEN, MG, NY), 1345 (MG, NY) and 1346 (MG); Barra do Corda, Loteamento Cidade Universitária, 05³2'39'S, 45¹5'59”W, 05.X.2015, fr., M.L. Guedes et al. 23998 (ALCB); Carolina, top of Serra da Madeira, $07^{\circ} 11^{\prime} \mathrm{S}$, 47²6'W, 04.VII.1993, fr., J.A. Ratter et al. 6738 (UB); Carolina, Parque Nacional da Chapada das Mesas, acesso a E no km 600 da BR-230, 47

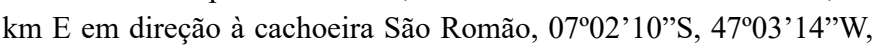
11.IV.2016, fl. and fr., M.F. Simon et al. 2889 (CEN); Colinas, Fazenda

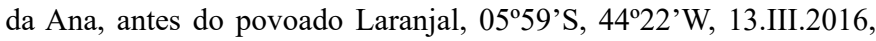
fr., G.P. Lima 622 and 623 (MAR); Colinas, Povoado São Domingos, 29.VII.2016, st., P.M. Santos 319 (SLUI); Estreito, Canteiro de obras da UHE de Estreito, 06³5'29”S, 47²7'34”W, 10.III.2007, fr., G. Pereira-Silva \& G.A. Moreira 11365 (CEN); Loreto, "Ilha de Balsas" region, between the rios Balsas and Parnaíba, ca. $5 \mathrm{~km} \mathrm{~N}$ of city of Ribeiro Gonçalves along jeep road between "Côco da Aparecida" \& rio Panaíba, 02.IX.1963, fr., G. Eiten \& L.T. Eiten 5449 (SP); Porto Franco, 06¹8'00"S, 47²0'24”W, 18.VII.2017, st., C.A. Sousa 322 (UB); São Luís, estrada do Olho D’Água, II-III.1939, fl., R. Fróes 11622 (NY); São Luís, 14.XII.1958, fl. and fr., W.A. Egler 739 (MG); São Luís, Reserva Florestal do Sacavém (Parque Estadual do Bacanga), próximo à rodoviária, 27.VII.1994, st., L.R. Noblick \& N. Figueiredo 4965 (MAR); São Luís, Bacanga, próximo ao Centro de Ciências Exatas e Tecnologia (CCET) da UFMA, 20.V.2015, fl. and fr., G.P. Prazeres 01 (MAR); São Luís, Bacanga, UFMA, próximo ao prédio de Educação Física, 02³3'48”S 44¹8'43”W, 10.IV.2017, st., G.P. Lima 646 (MAR); Timom, 30.I.1981, fl., D. Andrade-Lima 81-9018
(IPA); Tuntum, Palmerinhas, on unpaved road S from BR-226, between Presidente Dutra and Barra do Corda, 05 ${ }^{\circ} 14^{\prime}$ 'S, 44 $28^{\circ}$ 'W, 26.II.1983, st., E.L. Taylor et al. 1049 (MG); s.1., 23.VIII.1976, st., D. AndradeLima 76-8256 (IPA).

22. Syagrus comosa (Mart.) Mart., Voy. Amér. Mér. 7(3): 134. 1847. Figure 10c-e.

Syagrus comosa is a solitary and caulescent palm with 1-5 $\mathrm{m}$ tall that differs from the other caulescent species of the genus Syagrus by the stem covered with remnants leaf sheaths, the rounded pistillate flowers, and the ellipsoid fruits with less than $3 \mathrm{~cm}$ in length. Noblick (2017) mentions the occurrence of acaulescent individuals with unbranched inflorescence; however, this variation was not observed in this study.

Common names: catolé, pati, coco-babão, gabiroba-catolé, guariroba-do-campo, indaiá, and palmito-amargoso.

Distribution and ecology: This taxon occurs in large part of the Brazilian Cerrado, encompassing the states of Bahia, Goiás, Maranhão, Mato Grosso, Mato Grosso do Sul, Minas Gerais, Pará, Piauí, São Paulo and Tocantins, besides the Distrito Federal. Also, it may be found in the Bolivian Cerrado (Noblick 2017). In Maranhão, samples were collected in the southern region of the State (Figure 8b), with flowers in March, May and September, and fruits from June to December. According to Noblick (2017), the flowering and fruiting events occur during all year, however the flowering peaks occurs more intensely from March to May and fruiting from August to February.

Conservation: According to IUCN (2012) criteria, S. comosa is classified as Near Threatened (NT) for Maranhão since it has an EOO $\left(21,174.359 \mathrm{~km}^{2}\right)$ close to the threshold for the threat category $(\mathrm{EOO}<$ $20,000 \mathrm{~km}^{2}$ ). Moreover, this species was only reported in nine locations in the State, with only one of these locations within a conservation unit (Mirador State Park). The other samples were collected in the town of Balsas, where a large portion of the Cerrado has been impacted due to soybean cultivation (Barreto et al. 2012). On the other hand, Noblick (2017) classified this species as Least Concern (LC) for Brazil, due to its wide distribution and by its presence within the limits of several protected areas.

Material examined: BRAZIL, MARANHÃO: Balsas, ca. 25 km W of Balsas, Fazenda of Sr. Damion, 04.XII.1981, fr., M.J. Balick et al. 1344 (MG, NY); Balsas, condomínio Kissy, lote 23, 10.III.1996, fl., G. Pereira-Silva 3501 (CEN, TEPB); Balsas, Projeto Geral de Balsas - Lote $16,07^{\circ} 35^{\prime}$ S, $46^{\circ} 05^{\prime}$ W, 08.XI.1996, fr., R.C. Oliveira \& G. Pereira-Silva 375 (HEPH); Balsas, Agrovila Nova de Carli - lote 19, 0841'32”S, 4645'45”'W, 05.VII.1998, fr., R.C. Oliveira et al. 1270 (HEPH); Balsas, Projeto de Colonização Agrícola Gerais de Balsas, Região da Vila Kissy após o rio Tem Medo (Lote 16), 08³8'S, 46²43'W, 13.III.2000, fl., B.M. Walter et al. 4412 (CEN); Balsas, estrada entre Balsas e a localidade Santa Luzia, 07³6'18”'S, 4606'45”W, 11.XII.2014, fr., M.M. Toledo \& M.M. Cavallari 11 (CEN); Loreto, 50-60 km south of Loreto, along jeep road between "Sítio" and "Côco de Aparecida", 7³0'S, 45¹5'W, fr., 03.IX.1963, G. Eiten \& L.T. Eiten 5456 (SP); Mirador, Parque Estadual do Mirador, 26.IX.1988, fl., F. Nobeto et al. 123 (MG, SLUI); Tasso Fragoso, 09¹6’02”S, 4559'03”W, 13.V.2013, fl., P.M. Santos et al. $390(\mathrm{MBM})$.

23. Syagrus glazioviana (Dammer) Becc., Agric. Colon. 10: 466. 1916. Figure 11a-c. 
Synopsis of the tribe Cocoseae Mart. in Maranhão
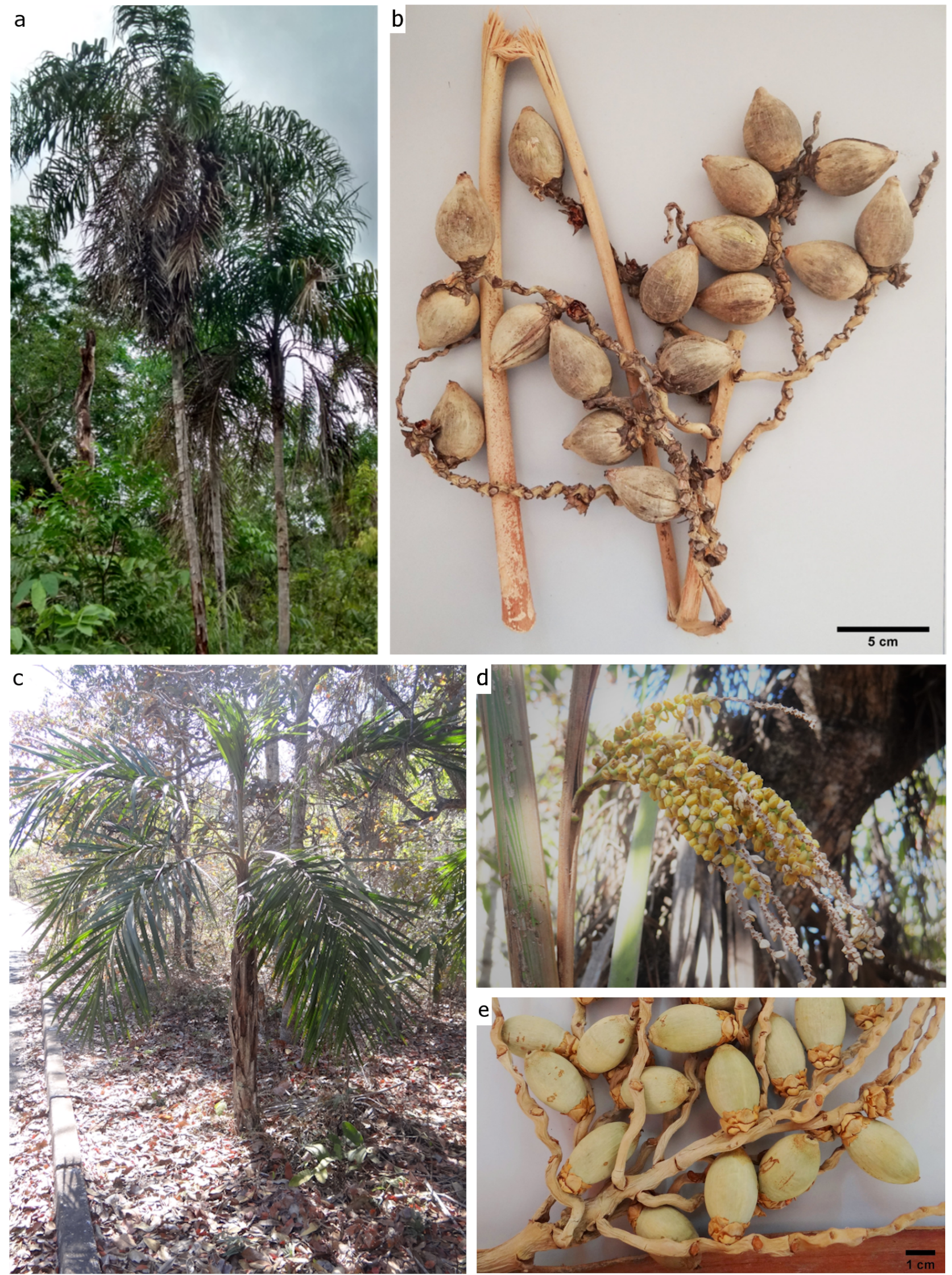

Figure 10. a-b. Syagrus cocoides. a. palm in its natural environment (G.P. Lima 622); b. piriform fruits (G. Pereira-Silva et al. 5356). c-e. Syagrus comosa; c. palm with stem covered with remnants leaf sheaths; $d$. inflorescence with various rachillae; e. fruits (G. Pereira-Silva 3501). 

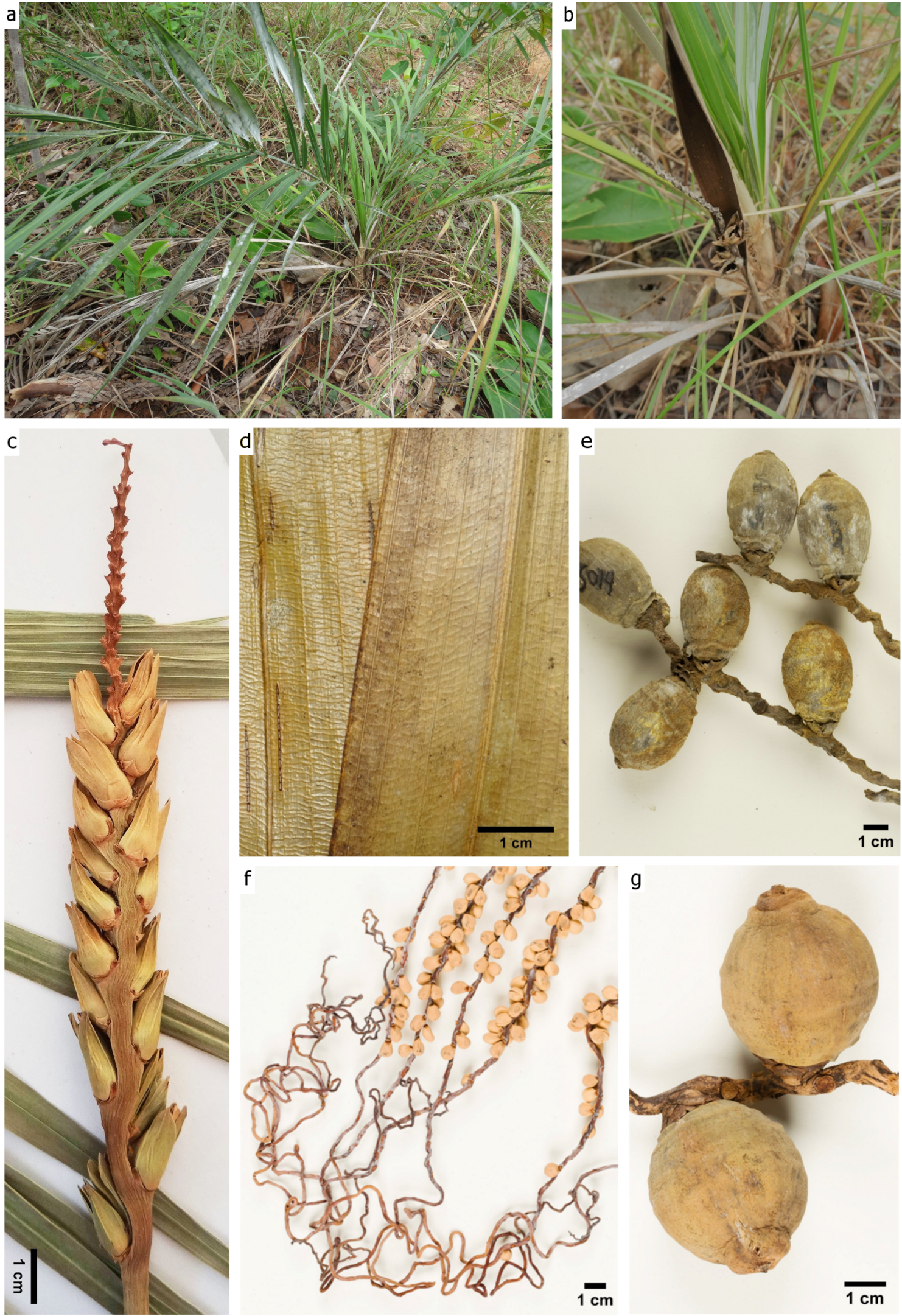

Figure 11. a-c. Syagrus glazioviana; a. palm with acaulescent habit (A.W.C. Ferreira s.n.); b. inflorescence supported near ground level (A.W.C. Ferreira s.n.); c. unbranched inflorescence ((M.F. Simon et al. 2824). d-e. Syagrus inajai; d. cross-veins on the abaxial surface of the pinnae (A.J. Henderson et al. 1157); e. fruits (L.R. Noblick 5014). f-g. Syagrus vermicularis; f. coiled and twisted rachillae, and with the apexes devoid of flowers (L.R. Noblick et al. 4971); g. fruits (L.R. Noblick et al. 4971). 
Solitary and acaulescent palm with $0.5-1 \mathrm{~m}$ tall characterized by its underground stem, its small number of pinnae along each side of the rachis (15-31), and its unbranched inflorescence. The other species of the genus Syagrus have aerial stem, more pinnae along each side of the rachis ( $>40)$, and branched inflorescence up to first order. Noblick (2019) mentions the occurrence of individuals with branched inflorescence; however, this variation was not observed in this study.

Common names: tucum-de-índio, ariri, acumã, côco-de-raposa, côco-de-vassoura, coquinho-da-serra, and guriri.

Distribution and ecology: This palm is endemic in Brazil and it is found in Bahia, Goiás, Mato Grosso, Minas Gerais, Piauí, and Tocantins. It grows in variable habitat and soil types within the Cerrado biome, from forested environments to open environments (Noblick 2017). According to this research, the distribution area is expanded to the south and southwest of Maranhão. The new records of occurrences were found in Mirador State Park and Chapada das Mesas National Park (Figure 8b), in cerrado stricto sensu, with flowers in February, April and September, and fruits in September and December. According to Noblick (2017), this species appears to flower and fruit year-round, but most specimens collected with flowers in September and October.

Conservation: $S$. glazioviana is assessed as Vulnerable [VU $\mathrm{B} 1 \mathrm{ab}(\mathrm{iii})$ ] for Maranhão since it has EOO of 5,766.590 $\mathrm{km}^{2}$ and has only four different records of occurrence. Almost all the specimens of the taxon were recorded within the limits of two conservation units: Mirador State Park and Chapada das Mesas National Park. Outside of these protected areas, the viability of the species is even more uncertain, considering the marked decline in the extent and quality of habitat already observed and also projected for the next years in the Maranhão Cerrado (Barreto et al. 2012). Noblick (2017) considered this species as Least Concern (LC) in the national context, due to its presence in several Brazilian states, within the borders of national parks and in relatively untouched areas of Cerrado that are unsuitable for soybean production.

Material examined: BRAZIL, MARANHÃO: Carolina, Parque Nacional da Chapada das Mesas, 07²0'43"S, 4656'49”'W, 09.IV.2014, fl., M.F. Simon et al. 2824 (CEN); Estreito, road between Estreito and Carolina, $23 \mathrm{~km}$ south of Estreito, 06 ${ }^{\circ} 45^{\prime}$ S, 47 $7^{\circ} 20^{\prime} \mathrm{W}, 01$.XII.1981, fr., J. Jangoux et al. 1772 (MG); Mirador, Parque Estadual do Mirador, Base Geraldina, 06³6'54”S 4551'27’W, 30.IX.2015, fr., G.P. Lima 753 (MAR); Mirador, Parque Estadual do Mirador, Base Geraldina, 14.II.2017, fl., A.W.C. Ferreira s.n. (MAR).

24. Syagrus inajai (Spruce) Becc., Agric. Colon. 10: 467. 1916. Figure 11d-e.

Solitary and caulescent palm with 4-20 m tall that resembles Syagrus cocoides, but it can be distinguished by its smooth stem and its prominent cross-veins on the abaxial and adaxial surfaces of the pinnae.

Common names: curuarana, pati-açu, marari’y (Ka'apor), jarevá, mamariro, pirima, piririma, pupunharana, pupunharana-brava, and pupunha de porco.

Distribution and ecology: In Brazil, this palm occurs in Amapá, Amazonas, Maranhão, and Roraima, inhabiting terra firme forests and gallery forests, as well as swamp areas (Noblick 2017). It also occurs in French Guiana and Suriname. Also, it is reported to occur in Guyana, but to date, no records have been found in herbaria (Noblick 2017). In Maranhão, specimens were obtained in areas of the Amazon forest in the western region (Figure 8b), with fruits in May and September only.
Conservation: Syagrus inajai is assessed as Data Deficient (DD) for Maranhão, given the small number of known specimens. Thus, more field efforts are required to clarify its occurrence in the State, so that the conservation status can be properly assessed. Concerning its distribution in the Neotropical region, this species is considered by Noblick (2017) as Least Concern (LC), because it is found within the limits of several protected areas in Brazil and French Guiana.

Material examined: BRAZIL, MARANHÃO: Ka'apor Indian Reserve (T.I. Alto Turiaçu), 10.V.1986, fr., W.L. Balée 2303 (MG, NY); Santa Luzia, 1-2 km NE of Buriticupu along BR-222, 04 $18^{\circ} \mathrm{S}$, 46³2’W, 04.IX.1994, fr., L.R. Noblick 4970 (IPA, NY).

25. Syagrus vermicularis Noblick, Palms 48(3): 109-116. 2004. Figure 11f-g.

Syagrus vermicularis is a solitary and caulescent palm with 6-10 $\mathrm{m}$ tall that can be distinguished from the others Syagrus species by its coiled and twisted rachillae like a "spaghetti", as pointed out by Noblick (2017). In addition, the apex of these structures are entirely devoid of flowers.

Common name: pati.

Distribution and ecology: A species endemic in Brazil, occurring in the states of Maranhão, Pará, and Rondônia. Probably, it occurs in Mato Grosso and Tocantins, however, specimens have not yet been found in those states (Noblick 2017). It usually grows in semideciduous forests, transitional areas and humid tropical forest, mainly in secondary vegetations and open pastures (Noblick 2017). In Maranhão, S. vermicularis was only found in the town of Açailândia (Figure 8b), with flowers and fruits in September. According to Noblick (2017), the flowering and fruiting periods occur between August and November, based on cultivated individuals of the Montgomery Botanical Center in Florida.

Conservation: Following the IUCN (2012) criteria B1, this species was assessed as Data Deficient (DD) for Maranhão since it has less of three unique occurrence records. However, Noblick (2017) categorized S. vermicularis as Vulnerable (VU A2c) for Brazil, due to the severe logging practices in its natural habitats. Considering this last evaluation, we highlight that further surveys in western Maranhão are needed so that it will be possible to assess the conservation status of this palm in the State territory.

Material examined: BRAZIL, MARANHÃO: Açailândia, Fazenda Itaibaiana (Companhia Vale do Rio Doce), ca. $17 \mathrm{~km} \mathrm{~S}$ on BR-110 km 1398, 06.IX.1994, fl. and fr., L.R. Noblick \& J.A. Feitosa 4971 (NY); Açailândia, 5-6 km S of the city on BR-010, 08.IX.1994, fl. and fr., L.R. Noblick et al. 4974 (IPA).

\section{Supplementary material}

The following online material is available for this article: Appendix - List of additional material examined.

\section{Acknowledgments}

We thank the Fundação de Amparo à Pesquisa e ao Desenvolvimento Científico e Tecnológico do Maranhão (FAPEMA) for the master's scholarship of the first author, Coordenação de Aperfeiçoamento de Pessoal de Nível Superior, finance code 001, and to Programa de 
Pós-Graduação em Biodiversidade e Conservação (PPGBC) of the Universidade Federal do Maranhão for the financial support in the travels. We also are grateful to the curators and technicians of the herbaria by the readiness and access to their collections, to Alessandro Wagner Ferreira for his assistance with collected specimens and photographs, and to Claudio Urbano Pinheiro for the loan of essential bibliographies.

\section{Author Contributions}

Gustavo Pereira Lima: substantial contribution in the concept and design of the study; contribution to data collection; contribution to data analysis and interpretation; contribution to manuscript preparation, and contribution to critical revision, adding intellectual content.

Eduardo Bezerra de Almeida Jr:: substantial contribution in the concept and design of the study; contribution to manuscript preparation, and contribution to critical revision, adding intellectual content.

\section{Conflicts of Interest}

The authors declare that they have no conflict of interest related to the publication of this manuscript.

\section{References}

ANDERSON, A.B., OVERAL, W.L. \& HENDERSON, A. 1988. Pollination Ecology of a Forest-Dominant Palm (Orbignya phalerata Mart.) in Northern Brazil. Biotropica 20(3):192-205.

APG IV. 2016. An update of the Angiosperm Phylogeny Group classification for the orders and families of flowering plants: APG IV. Bot. J. Linn. Soc. 181(1):1-20.

BAKER, W. \& DRANSFIELD, J. 2016. Beyond Genera Palmarum: progress and prospects in palm systematics. Bot. J. Linn. Soc. 182(2):207-233.

BALICK, M., PINHEIRO, C.U.B. \& ANDERSON, A.B. 1987. Hybridization in the Babassu Palm Complex: I. Orbignya phalerata x O. eichleri. Am. J. Bot. 74(7):1013-1032.

BALSLEV, H., BERNAL, R. \& FAY, M.F. 2016. Palms - emblems of tropical forests. Bot. J. Linn. Soc. 182(2):195-200.

BARRETO, L., VAN EUPEN, M., KOK, K., JONGMAN, R.H.G., RIBEIRO, M.C., VELDKAMP, A., HASS, A., OLIVEIRA, T.G. The impact of soybean expansion on mammal and bird, in the Balsas region, north Brasilian Cerrado. J. Nat. Conserv. 20(6):374-383.

CELENTANO, D., ROUSSEAU, G.X., MUNIZ, F.H., VARGA, I.V.D., MARTINEZ, C., CARNEIRO, M.S., MIRANDA, M.V.C., BARROS, M.N.R., FREITAS, L., NARVAES, I.S., ADAMI, M., GOMES, A.R., RODRIGUES, J.C. \& MARTINS, M.B. 2017. Towards zero deforestation and forest restoration in the Amazon region of Maranhão state, Brazil. Land Use Policy 68:692-698.

CNCFLORA. 2019. Lista Vermelha. Centro Nacional de Conservação da Flora. http://cncflora.jbrj.gov.br/portal/pt-br/listavermelha (last access in 15/04/2019).

DRANSFIELD, J. 1986. A Guide to Collecting Palms. Ann. Missouri Bot. Gard. 73(1):166-176.

FAVA, W.S., COVRE, W.S. \& SIGRIST, M.R. 2011. Attalea phalerata and Bactris glaucescens (Arecaceae, Arecoideae): Phenology and pollination ecology in the Pantanal, Brazil. Flora 206(6):575-584.

FLORA DO BRASIL 2020. [ under construction]. Jardim Botânico do Rio de Janeiro. http://floradobrasil.jbrj.gov.br (last access in 15/04/2019).

GIMP TEAM. 2019. GNU Image Manipulation Program 2.10.6. http://www. gimp.org_(last access in 27/02/2019).

GLASSMAN, S.F. 1999. A Taxonomic Treatment of the Palm Subtribe Attaleinae (Tribe Cocoeae). Ill. Biol. Monogr. 59:1-414.
HARRIS, J.G. \& HARRIS, M.W. 1994. Plant identification terminology: An illustrated glossary. 2 ed. Spring Lake Pub, Spring Lake.

HENDERSON, A. 1990. Arecaceae. Part I. Introduction and the Iriarteinae. Flora Neotrop. 53:1-100.

HENDERSON, A., GALEANO, G. \& BERNAL, R. 1995. Field Guide to the Palms of the Americas. Princeton University Press, New Jersey.

HENDERSON, A. 2000. Bactris (Palmae). Flora Neotrop. 79:1-181.

HENDERSON, A. 2011. A revision of Desmoncus (Arecaceae). Phytotaxa $35: 1-88$

IMESC. 2008. Perfil do Maranhão 2006/2007. Instituto Maranhense de Estudos Socioeconômicos e Cartográficos, São Luís.

IUCN. 2012. IUCN Red List Categories and Criteria: Version 3.1. 2 ed. IUCN, Gland e Cambridge.

JOHNSON, D.V. 1998. Non-wood forest products 10: tropical palms. Food and Agriculture Organization of the United Nations (FAO). http://www.fao.org/ docrep/x0451e/x0451e00.HTM_(last access in 15/04/2019).

KAHN, F. 1990. Identification of Amazonian Palm Genera from vegetative characters. Principes 34(4):199-207.

KAHN, F. 2008. The genus Astrocaryum (Arecaceae). Rev. Peru. Biol. 15(supl. 1):31-48.

LENTZ, D. 1990. Acrocomia mexicana: palm of the ancient Mesoamericans. J. Ethnobiol. 10(2):183-194.

LORENZI, H., NOBLICK, L.R., KAHN, F. \& FERREIRA, E. 2010. Flora Brasileira: Arecaceae (Palmeiras). Instituto Plantarum, Nova Odessa.

MACHADO, M.A. \& PINHEIRO, C.U.B. 2016. Da água doce à água salgada: mudanças na vegetação de igapó em margens de lagos, rios e canais no baixo curso do rio Pindaré, Baixada Maranhense. Rev. Bras. Geogr. Fís. 9(5):1410-1427.

MARTINS, R.C. \& FILGUEIRAS, T.S. 2010. Roteiro morfológico para a coleta de palmeiras (Arecaceae) no Cerrado. Heringeriana 4(1):51-59.

MARTINS, R.C., FILGUEIRAS, T.S., GRACIANO-RIBEIRO, D. \& SOMAVILLA, N.S. 2015. A new species of Allagoptera (Arecaceae) from the Cerrado of central Brasil. Phytotaxa 197(2):115-124.

MEEROW, A.W., NOBLICK, L., SALAS-LEIVA, D.E., SANCHEZ, V., FRANCISCO-ORTEGA, J., JESTROW, B. \& NAKAMURA, K. 2015. Phylogeny and historical biogeography of the cocosoid palms (Arecaceae, Arecoideae, Cocoseae) inferred from sequences of six WRKY gene family loci. Cladistics 31(5):509-534.

MIC/STI. 1982. Mapeamento e levantamento o potencial das ocorrências de babaçuais: estados do Maranhão, Piauí, Mato Grosso e Goiás. Embrapa, Brasilia.

MORAES, M. 1996. Allagoptera (Palmae). Flora Neotrop. 73:1-34.

MUNIZ, F.H. 2006. A vegetação da região de transição entre a Amazônia e o Nordeste: diversidade e estrutura. In Agroambientes de transição: entre o trópico úmido e semi-árido do Brasil (E.G., Moura, org.). 2 ed. UEMA, São Luís, p. 53-70.

NOBLICK, L.R., HAHN, W.J. \& GRIFFITH, M.P. 2013. Structural cladistic study of Cocoseae, subtribe Attaleinae (Arecaceae): Evaluating taxonomic limits in Attaleinae and the neotropical genus Syagrus. Brittonia 65(2):232261.

NOBLICK, L.R. \& MEEROW, A.W. 2015. The Transfer of the Genus Lytocaryum to Syagrus. Palms 59(2):57-62.

NOBLICK, L.R. 2017. A revision of the genus Syagrus (Arecaceae). Phytotaxa 294(1):1-262.

NOBLICK, L.R. 2019. Guia para as palmeiras do Nordeste do Brasil. UEFS Editora, Feira de Santana.

OLIVEIRA, M.S.P., COUTURIER, G. \& BESERRA, P. 2003. Biologia da polinização da palmeira tucumã (Astrocaryum vulgare Mart.) em Belém, Pará, Brasil. Acta Bot. Bras. 17(3):343-353.

PALMWEB. 2019. Palmweb: Palms of the World Online. http://palmweb.org (last access in 14/04/2019).

PINHEIRO, C.U.B. 2011. Palmeiras do Maranhão: Onde canta o sabiá. Gráfica e Editora Aquarela, São Luís. 
PINTAUD, J.C., GALENO, G., BALSLEV, H., BERNAL, R., BORCHSENIUS, F., FERREIRA, E., GRANVILLE, J.J., MEJÍA, K., MILLÁN, B., MORAES, M., NOBLICK, L., STAUFFER, F.W. \& KAHN, F. 2008. Las palmeras de América del Sur: diversidad, distribución e historia evolutiva. Rev. Peru. Biol. 15(supl. 1):7-29.

PIRES, H.C.G., ROSA, L.S., CABRAL, B.S. \& FERREIRA, P.R.N. 2016 Padrão Fenológico de Attalea maripa (Aubl.) Mart. em Áreas de Pastagens na Amazônia Oriental. Floresta Ambient. 23(2):170-179.

QGIS DEVELOPMENT TEAM. 2019. QGIS Geographic Information System. Open Source Geospatial Foundation. https://www.qgis.org_(last access in 13/04/2019).

SCARIOT, A.O., LLERAS, E. \& HAY, J.D. 1991. Reproductive biology of the Palm Acrocomia aculeata in Central Brazil. Biotropica 23(1):12-22.

SOARES-FILHO, B., RAJÃO, R., MACEDO, M., CARNEIRO, A., COSTA, W., COE, M., RODRIGUES, H. \& ALENCAR, A. 2014. Cracking Brazil's Forest Code. Science 344:363-364.
THIERS, B. [continuously updated]. Index Herbariorum: A global directory of public herbaria and associated staff. New York Botanical Garden's Virtual Herbarium. http://sweetgum.nybg.org/science/ih/ (last access in em 15/04/2019).

TROPICOS. 2019. Missouri Botanical Garden. http://www.tropicos.org (last access in 09/04/2019).

ZAMBRANA, N.Y.P., BYG, A., SVENNING, C.C., MORAES, M., GRANDEZ, C. \& BALSLEY, H. 2007. Diversity of palm uses in the western Amazon. Biodivers. Conserv. 16(10):2771-2787.

Received: 20/11/2019

Revised: $28 / 03 / 2020$

Accepted: $17 / 04 / 2020$

Published online: 19/06/2020 